Article

\title{
The Role of Humoral Innate Immunity in Hepatitis C Virus Infection
}

\author{
Alexander W. Tarr *, Richard A. Urbanowicz and Jonathan K. Ball \\ Biomedical Research Unit in Gastroenterology, School of Molecular Medical Sciences, \\ Faculty of Medicine and Health Sciences, University of Nottingham, Nottingham, NG7 2UH, UK; \\ E-Mails: rich.urbanowicz@nottingham.ac.uk (R.A.U.); jonathan.ball@nottingham.ac.uk (J.K.B.) \\ * Author to whom correspondence should be addressed; E-Mail: alex.tarr@nottingham.ac.uk.
}

Received: 7 December 2011; in revised form: 21 December 2011 / Accepted: 23 December 2011 / Published: 5 January 2012

\begin{abstract}
Infection with Hepatitis C Virus (HCV) causes chronic disease in approximately $80 \%$ of cases, resulting in chronic inflammation and cirrhosis. Current treatments are not completely effective, and a vaccine has yet to be developed. Spontaneous resolution of infection is associated with effective host adaptive immunity to $\mathrm{HCV}$, including production of both HCV-specific T cells and neutralizing antibodies. However, the supporting role of soluble innate factors in protection against HCV is less well understood. The innate immune system provides an immediate line of defense against infections, triggering inflammation and playing a critical role in activating adaptive immunity. Innate immunity comprises both cellular and humoral components, the humoral arm consisting of pattern recognition molecules such as complement $\mathrm{Clq}$, collectins and ficolins. These molecules activate the complement cascade, neutralize pathogens, and recruit antigen presenting cells. Here we review the current understanding of anti-viral components of the humoral innate immune system that play a similar role to antibodies, describing their role in immunity to $\mathrm{HCV}$ and their potential contribution to $\mathrm{HCV}$ pathogenesis.
\end{abstract}

Keywords: innate immunity; hepatitis $\mathrm{C}$ virus; complement; defensin; pentraxin; collectin; mannose binding lectin; ficolin; pathogenesis; fibrosis 


\section{Virus-Host Interactions in the Acute Phase of HCV Infection}

Hepatitis C Virus (HCV) infects approximately 170 million people worldwide, resulting in chronic, progressive disease in $80 \%$ of infected individuals. Infection is characterized by progressive liver damage, resulting in fibrosis and cirrhosis. In $5 \%$ of chronic infections hepatocellular carcinoma develops, necessitating liver transplantation. An acute, self limiting infection occurs in $20 \%$ of infections [1]. It is believed that control of infection is determined by the interplay between virus and the host immune system [2]. Greater understanding of the virus-host interactions in resolving infections is required to identify correlates of clearance and is an essential for development of new therapeutic interventions and effective vaccines.

Studies of the early stages of HCV infection are limited by the generally asymptomatic nature of infection soon after transmission. Infections are often undiagnosed until clinical presentation of symptoms. As a consequence much of our understanding of viral kinetics in the early stages of infection comes from experimental infection of primates. Both spontaneously resolving and persistent infections have high viral load in the first few weeks [3]. This results in production of HCV-specific T cells within 2-5 weeks [4,5]. Seroconversion occurs approximately 6-8 weeks after infection [6], following the initial T-cell response. Adaptive immunity is believed to make an important contribution to spontaneous resolution. Clearance has been associated with a strong, broadly-targeted $\mathrm{T}$ cell response [5,7-9], and the rapid production of broadly neutralizing antibodies [10,11]. However, there is no clear consensus; spontaneous resolution of $\mathrm{HCV}$ infection can occur in agammaglobulinemic individuals, [12], and $\mathrm{T}$ cell responses are not always correlated with resolving infection [13]. The protective effect of host immunity is likely to be multi-factorial, comprising both adaptive and innate components. Many studies have assessed host humoral adaptive immunity in chronic and spontaneously resolving infections [11,14-16]. However these studies have attributed anti-viral properties of sera only to the presence of antibodies. It is likely that this underestimates the contribution of innate factors to spontaneous clearance [17] and protection from re-infection [18].

Despite advances in our understanding of the role of adaptive response to HCV infection, much less is known about the contribution of acute-phase immune factors to clearance and the innate humoral defenses that act during chronic infection. The mammalian immune system has evolved both innate and adaptive arms to act co-operatively, protecting against infection and limiting the damage caused by invading pathogens. Innate immunity acts immediately following infection, directing production of pro-inflammatory cytokines and orchestrating presentation of antigens to T- and B cells. There is clear evidence that this interplay is essential in clearing viral infections [19,20]. In HCV infections, spontaneous clearance is associated with IFN- $\gamma$ production $[8,21]$ and production of proteins associated with antigen processing [22]. However, greater understanding of the interplay between innate and adaptive immunity in $\mathrm{HCV}$ infection is required to optimize therapies and vaccine strategies. Here we review the importance of innate humoral immune factors in virus infections and describe the accumulating evidence that this arm of the immune response is important in limiting HCV infection. There is evidence for direct anti-viral properties of some innate immune proteins, as well as indirect evidence inferred by the modulation of innate immune activity by virus-encoded proteins. The evidence for suppression of humoral innate immunity by HCV, and the role of these proteins in $\mathrm{HCV}$ pathogenesis are also considered. 


\section{The Role of Innate Immunity in Limiting HCV Infection}

The innate immune system has a number of roles in recognition and clearance of viral infections. It contributes to immune surveillance in organ systems and the circulation, directly neutralizing infection [23-25] as well as triggering inflammation, opsonizing pathogens, and modulating adaptive immunity [26-30]. Complex interplay occurs between cellular components of innate immunity, including monocytes, dendritic cells, platelets, Natural Killer cells and NKT cells. These cells detect pathogens and contribute to clearance by activating $\mathrm{T}$ cells and $\mathrm{B}$ cells and by directly degrading pathogens [31-34].

The function of innate immune cells is intimately linked with recognition by humoral innate immune proteins, a diverse group of proteins that act as Pattern Recognition Receptors (PRRs). These proteins recognize Pathogen-Associated Molecular Patterns (PAMPs) on the infecting virus particles, or presented on the surface of infected cells. These PRRs include pentraxins, and defense collagens such as C-type lectins and ficolins. In addition, elements of the complement cascade are responsible for recognition of pathogens, both directly and as part of immune complexes consisting of immunoglobulins cross-linked by viral antigens on the surface of virions or infected cells. The complement system and associated pathways also have functional effector properties, activating cascades of proteins responsible for opsonisation and lysis of enveloped virions and infected cells. Humoral innate proteins circulate in the bloodstream, and function both in the serum and in tissues.

The innate immune system is highly integrated with adaptive immunity. Soluble innate molecules can modulate antigen presentation [35-37], directing the specificity of T cells and antibodies. In turn, antibodies can trigger and modulate innate antiviral effector mechanisms, contributing to enhanced antigen presentation [38]. Humoral innate immune factors are produced by a number of cell types, including monocytes, lymphocytes, and hepatocytes. Importantly, hepatocytes are the primary source of the complement components, mannose binding lectin, and the ficolins L-ficolin and H-ficolin. Localized high concentrations of these proteins may accumulate in the liver and as such may have important anti-HCV activity at the site of replication. Infection of these cells with HCV might also result in increased production of soluble PRRs [39]. Greater understanding of the interplay between components of the innate immune system acting in the liver may reveal novel therapeutic targets.

\section{Induction of Acute Phase Proteins in Virus Infections}

Initiation of a protective adaptive immune response to $\mathrm{HCV}$ infection follows inflammation and as such is dependent on an effective acute phase innate immune response. The inflammatory response is initiated by the presence of virus particles and subsequent infection of hepatocytes. Binding of microbial PAMPs, such as HCV glycoproteins, to antigen presenting cells results in activation and initiation of the inflammatory response and presentation of viral antigens to $\mathrm{T}$ cells [40-45]. Activation of these cells by viral proteins results in production of the soluble cytokines IL-1 $\alpha$, IL-1 $\beta$ and TNF- $\alpha$, and the IL-6 family of cytokines, which in turn stimulate hepatocytes to produce acute-phase proteins. These proteins are classified as Class I or Class II. Class I proteins include complement components, C-reactive protein (CRP), Serum Amyloid A, and $\alpha 1$-acid glycoprotein. These are induced by the action of IL- $1 \alpha$, IL-1 $\beta$ and TNF- $\alpha$. Class II proteins are induced by IL-6 produced from macrophages, 
and include fibrinogen, haptoglobin, $\alpha 1$-antichmotrypsin and $\alpha 1$-antitrypsin (reviewed in [46]). These acute phase proteins have roles in hemostasis, increased phagocytosis, and antithrombotic pathways, helping regulate inflammation while mediating clearance of the pathogen. Some of these proteins have a role in pathogen detection, and combine with the constitutively circulating PRRs to recognize pathogens and recruit cells for priming of adaptive immunity (Figure 1).

Figure 1. Overview of the production of soluble innate proteins involved in innate recognition of Hepatitis C Virus (HCV) antigens. Infected cells produce type I interferons, supporting activation of the inflammatory response. Antigen presenting cells such as monocytes and dendritic cells also recognize viral antigens, resulting in activation and production of defensins and pentraxins, as well as pro-inflammatory cytokines IL-6, TNF- $\alpha$, IL- $1 \alpha$ and IL-1 $\beta$. These cytokines induce production of acute phase proteins in hepatocytes such as complement components, pentraxins, and defensins, which contribute to clearance of viruses and infected cells. The hepatocytes are also a source of the defense collagens mannose binding lectin (MBL), and L \& $\mathrm{H}$ ficolins. These proteins recruit MBL-associated serine proteases (MASP-1 \& MASP-2), triggering the complement cascade and also activating liver-resident stellate cells that produce collagen, resulting in progressive fibrosis.

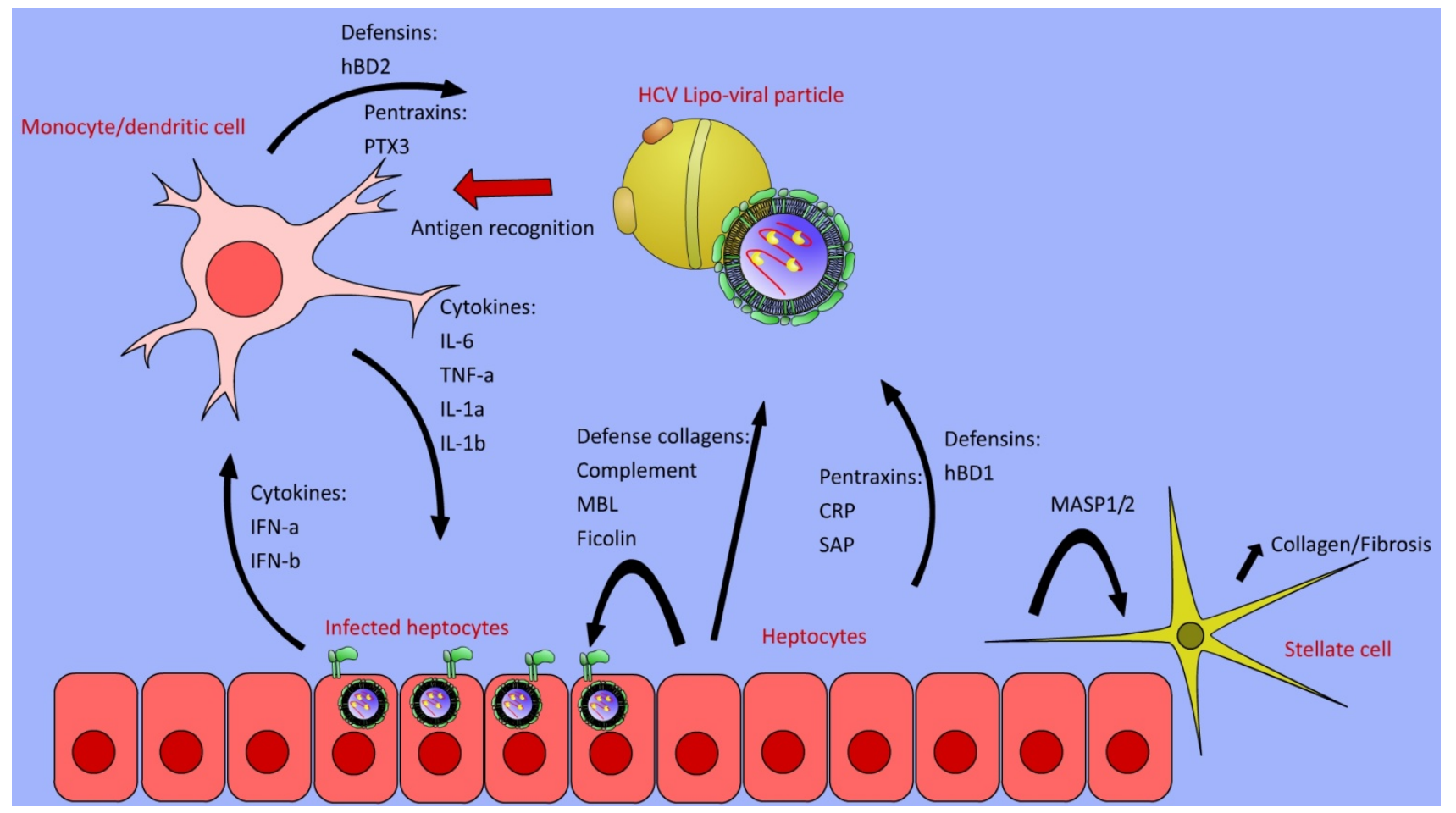

\section{Complement Cascade}

Complement is central to innate humoral immunity, interacting with a host of soluble and membrane proteins. In addition to the anti-bacterial activity of the complement cascade, this collection of acute phase proteins (C1q, C1r, C1s, and C2-C9) has a spectrum of antiviral activity. Complement components contribute to clearance of virus infections both directly and indirectly, contributing to lysis of enveloped virions [47,48] and virus infected cells [49,50], through the action of the C5-C9 
membrane attack complex. Many of the intermediate products of the complement cascade also act as potent opsonins, recruiting cellular immunity to phagocytose antigens and present viral peptides to $\mathrm{CD}^{+} \mathrm{T}$ cells. Innate immune cells including monocytes, macrophages and dendritic cells possess receptors $\mathrm{CR} 1, \mathrm{CR} 2, \mathrm{gC} 1 \mathrm{q}-\mathrm{R}$, and $\mathrm{cC} 1 \mathrm{q}-\mathrm{R}$, which bind to the complement/pathogen complexes and process them for activation of adaptive immunity.

Complement activation by virus infection occurs by five discrete mechanisms (Figure 2). Firstly, the C1qrs complex binds to antibodies captured by either virus-infected cells or virions. Co-localization of antibody molecules on an antigen results in binding of a bridging complex containing the multimeric recognition protein $\mathrm{C} 1 \mathrm{q}$, This recruits the serine proteases $\mathrm{C} 1 \mathrm{r}$ and $\mathrm{C} 1 \mathrm{~s}$, which catalyze cleavage of the $\mathrm{C} 4$ protein into $\mathrm{C} 4 \mathrm{a}$ and $\mathrm{C} 4 \mathrm{~b}$ subunits [51]. The second mechanism of action is direct binding of C1q viral surfaces, in the absence of immunoglobulin [52,53]. Thirdly, complement is activated by the lectin pathway. The family of ficolins and MBL both bind to glycosylated proteins, recruiting MBL-associated serine proteases (MASPs) to the surface of pathogens, which subsequently cleave the $\mathrm{C} 4$ protein [54]. Cleavage of $\mathrm{C} 4$ is a central event in the complement cascade, leading to sequential cleavage of $\mathrm{C} 2$, The complex of the cleavage products $\mathrm{C} 4 \mathrm{~b}$ and $\mathrm{C} 2 \mathrm{a}$ form a $\mathrm{C} 3$ convertase. $\mathrm{C} 3$ is cleaved into $\mathrm{C} 3 \mathrm{a}$ and $\mathrm{C} 3 \mathrm{~b}$ (Figure 3) [55]. The C3 cleavage product $\mathrm{C} 3 \mathrm{~b}$ is deposited on the surface of the pathogen. The fourth mechanism of activation is the spontaneous deposition of $\mathrm{C} 3 \mathrm{~b}$ onto virus particles. This is independent of recognition of pathogens by PRRs, as C3 is cleaved at a steady rate in the circulatory system by the combination of the activated form of Factor B (Bb), and Factor I. Deposition of the C3b component, either by $\mathrm{C} 2$ cleavage or spontaneous deposition, happens on the surface of virions and virus infected cells. C3b has multiple antiviral activities. It acts as a potent opsonin, recruiting antigen presenting cells to the viral antigen. It can also neutralize virus infectivity by aggregating virions. In addition, $\mathrm{C} 3 \mathrm{~b}$ in complex with either $\mathrm{C} 4 \mathrm{~b} 2 \mathrm{a}$, or Factor $\mathrm{Bb}$ forms the $\mathrm{C} 5$ convertase complex. This leads to deposition of $\mathrm{C} 5 \mathrm{~b}, \mathrm{C} 6, \mathrm{C} 7, \mathrm{C} 8$, and C9 proteins on a membrane, generating a membrane-puncturing pore. Other complement components have pro-inflammatory properties. The soluble cleavage products $\mathrm{C} 3 \mathrm{a}$ and $\mathrm{C} 5 \mathrm{a}$ also initiate inflammation [56], resulting in recruitment of monocytes and neutrophils.

The complement cascade is tightly regulated at every stage of activation, to prevent non-specific action of complement components, protecting host cells from lysis and autoimmune attack. A principal regulator of complement is Factor $\mathrm{H}$, which acts as a co-factor for the $\mathrm{C} 3 \mathrm{bBb}$. This protein binds to host glycosaminoglycans, inhibiting the action of the $\mathrm{C} 3$ convertase. The activity of $\mathrm{C} 3 \mathrm{~b}$ is also regulated following degradation into $\mathrm{iC} 3 \mathrm{~b}$ and $\mathrm{C} 3 \mathrm{~d}$ by Factor I. Complement deposition on host cells is inhibited by expression of the membrane proteins CD55 (Decay Accelerating Factor) and CD59 (Protectin), which inhibit the deposition of the $\mathrm{C} 3 \mathrm{bBb}$ complex, and the $\mathrm{C} 9$ membrane attack complex, respectively. In addition, the host membrane protein CD46 possesses cofactor activity for Factor I, which inactivates both $\mathrm{C} 4 \mathrm{~b}$ and $\mathrm{C} 3 \mathrm{~b}$.

The importance of complement to Flavivirus infections has been revealed by in vivo studies of West Nile Virus (WNV) infection. Deficiencies in C3, or complement receptors CR1 and CR2, result in increased WNV pathogenesis [57]. This protective effect is independent of C5a [58], suggesting a role for opsonisation in limiting pathogenesis. Both classical and lectin-mediated complement activation pathways contribute to protection [58,59]. Recruitment of complement component C1q can also modulate the stoichiometry of antibody neutralization, increasing the potency of specific monoclonal 
antibodies [60]. Despite these advances in understanding the pathology of WNV, there are still only limited investigations of the role of complement components in HCV infection. Complement enhances the neutralization of $\mathrm{HCV}$ pseudotypes by antibodies [61]. Although this finding has yet to be confirmed using natural $\mathrm{HCV}$ virions, it is plausible that results similar to those for WNV particles will be observed. Complement activation is observed in chronic HCV infection, but with reduced $\mathrm{C} 4$ activity [62] and concentration [63]. C4 may play a key role in HCV infection, as both HCV core and NS5A proteins cause reduction in $\mathrm{C} 4$ production by inhibiting transcription of $\mathrm{C} 4 \mathrm{mRNA}$ [63]. Greater $\mathrm{C} 4$ activity in $\mathrm{HCV}$ infections was also associated with better response to standard $\mathrm{HCV}$ treatment [62]. This implicates the complement pathway in resolving infection.

Figure 2. Mechanisms of recognition of viral pathogens by humoral innate proteins that result in complement activation. The widely recognised paths of complement activation include recognition of viral glycoproteins (in the case of HCV, glycoproteins E1 and E2) by: (a) antibody (Ab)-mediated C1q binding; (b) direct $\mathrm{Clq}$ binding; (c) mannose binding lectin (MBL); (d) ficolins; as well as (e) direct deposition of $\mathrm{C} 3 \mathrm{~b}$ on the surface of viruses or virus-infected cells following activation by Factor B. Additional mechanisms for complement activation by viruses are (f) pentraxin (PTX3) binding; and (g) binding of C1q to the human $\beta$-defensin HBD-2 inserted into a membrane. Complement activation by these recognition molecules is mediated by proteases that cleave the $\mathrm{C} 4$ protein. For $\mathrm{C} 1 \mathrm{q}$, these proteases are $\mathrm{C} 1 \mathrm{~s}$ and $\mathrm{C} 1 \mathrm{r}$. For MBL and ficolins these enzymes are MASP-1 and MASP-2. These ultimately result in $\mathrm{C} 3$ cleavage and generation of a $\mathrm{C} 5$ convertase complex. C3 cleavage can also occur spontaneously (e), resulting in C4-independent activation of $\mathrm{C} 5$. These diverse complement activation mechanisms highlight the broad range of pathogens that can be recognized and eliminated by the complement cascade.
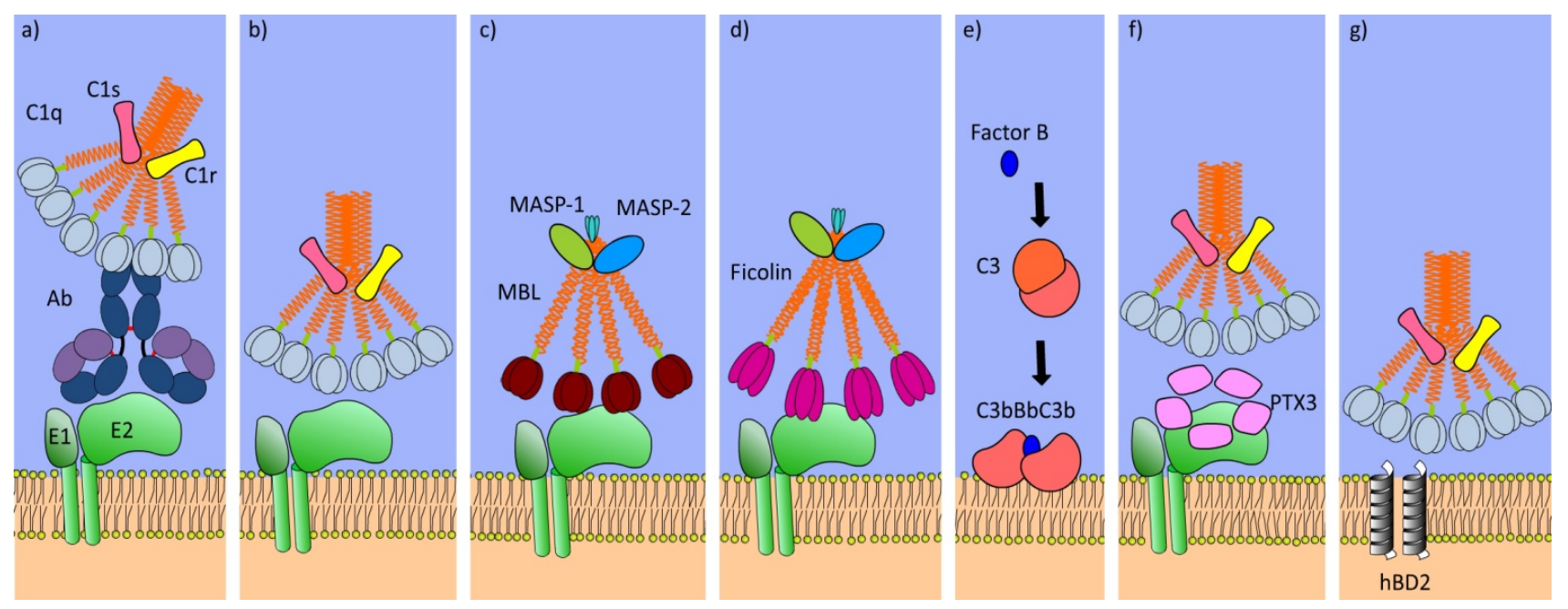

Indirect data also supports the hypothesis that complement has a role in protecting against $\mathrm{HCV}$ infection. A recent report suggests that HCV might incorporate CD59 into virus particles [64]. CD59 plays an essential role in preventing complement-mediated lysis of host cells. Present on most cell surfaces, CD59 binds to the C5b678 complex, preventing accumulation of the C9 proteins that form the membrane attack complex. Other viruses incorporate CD59 into their virions, including HIV-1, HTLV-1 and Vaccinia Virus [65-67]. It is plausible that HCV lipo-viral particles incorporate CD59 as 
a mechanism to prevent complement-mediated lysis of HCV virions. The contribution of complement to direct lysis of HCV virions, however, remains to be demonstrated.

The action of complement is modulated by complement receptors that bind C1q. The receptor $\mathrm{gClq}-\mathrm{R}$ is a multi-ligand binding protein expressed on the surface of monocytes and macrophages, as well as released from the surface of cells in soluble form. Protein $\mathrm{gC} 1 \mathrm{q}-\mathrm{R}$ has specificity for the globular head of the C1q molecule [68], as well as vitronectin and thrombin [69]. HCV core interacts directly with $\mathrm{gClq}-\mathrm{R}$ protein, resulting in reduced activation of $\mathrm{T}$ cells. Soluble $\mathrm{gClq}-\mathrm{R}$ is also found in serum in complex with core. Core protein mimics the structure of $\mathrm{Clq}$ sufficiently so that cross-reactive antibodies are produced during infection [70]. This implicates core in sequestering complement components and in preventing activation.

Figure 3. Components of the complement cascade. Initial recognition of pathogens occurs via pattern recognition molecules such as $\mathrm{C} 1 \mathrm{q}$ (pictured), mannose binding lectin (MBL), antibodies, and ficolins. Association with serine proteases, such as $\mathrm{C} 1 \mathrm{r}$ and $\mathrm{C} 1 \mathrm{~s}$ result in cleavage of $\mathrm{C} 4$ and $\mathrm{C} 2$, with the resultant $\mathrm{C} 4 \mathrm{~b} 2 \mathrm{a}$ membrane-bound complex cleaving $\mathrm{C} 3$. Addition of $\mathrm{C} 3 \mathrm{~b}$ to the $\mathrm{C} 4 \mathrm{~b} 2 \mathrm{a}$ complex results in the $\mathrm{C} 5$ convertase complex $\mathrm{C} 4 \mathrm{~b} 2 \mathrm{a} 3 \mathrm{~b}$. The Alternative pathway of complement pathway is activated by cleavage of $\mathrm{C} 3$ by Factor B. This results in deposition of the $\mathrm{C} 3 \mathrm{bBbC} 3 \mathrm{~b}$ complex on pathogen membranes, an alternative $\mathrm{C} 5$ convertase. Cleavage of $\mathrm{C} 5$ results in deposition of $\mathrm{C} 5 \mathrm{~b}$, recruitment of $\mathrm{C} 6$, $\mathrm{C} 7, \mathrm{C} 8$, which modulate the formation of the membrane attack complex made of oligomeric C9 protein. This causes lysis of enveloped virions, or virus-infected cells. The soluble cleavage products $\mathrm{C} 4 \mathrm{a}, \mathrm{C} 2 \mathrm{~b}, \mathrm{C} 3 \mathrm{a}$ and $\mathrm{C} 5 \mathrm{a}$ are potent opsonins, recruiting monocytes, neutrophils, and triggering inflammation. Hepatitis C Virus (HCV) interferes with the complement cascade at discrete steps. Both NS5a and Core proteins reduce the activity of $\mathrm{C} 4$. In addition, virus particles incorporate CD59 to prevent oligomerization of C9 on the surface of virus particles.

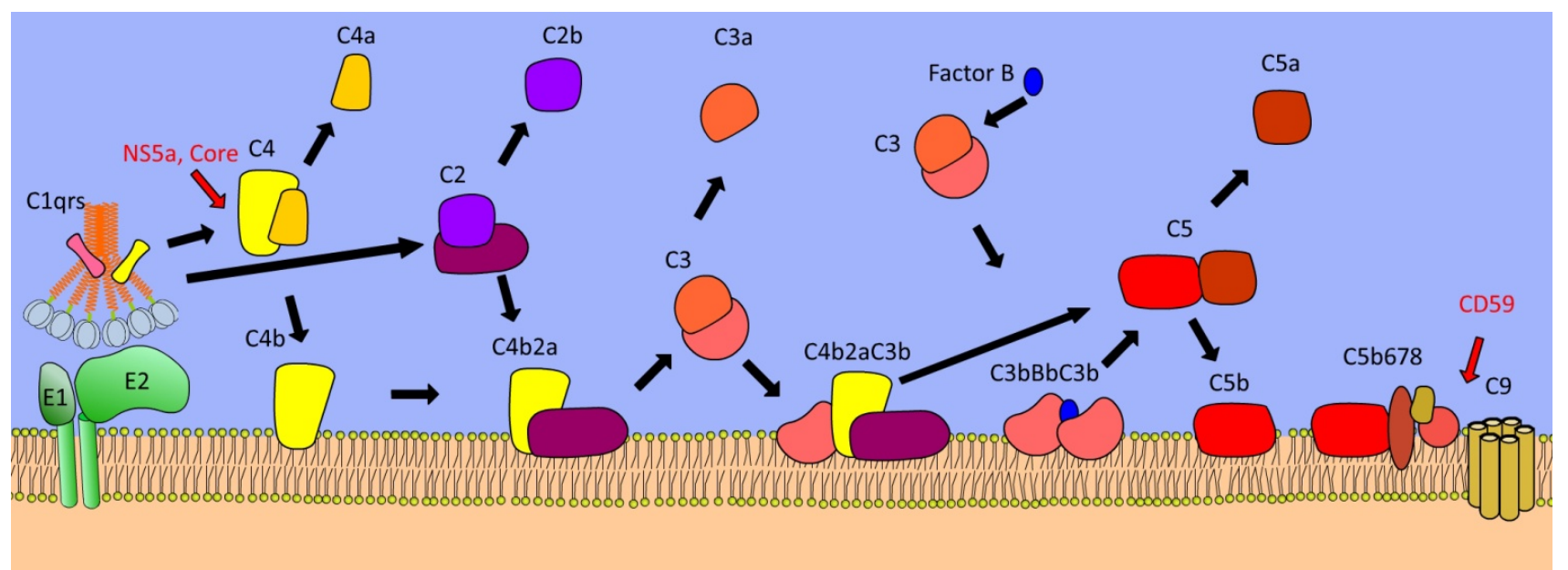

\section{Defense Collagens}

Complement component $\mathrm{C} 1 \mathrm{q}$ belongs to the family of defense collagen proteins. The complement cascade can also be activated by other members of this family, specifically the mannose-binding lectin 
(MBL) and the human ficolins, M-ficolin, L-ficolin and H-ficolin. In contrast to antibodies, these defense collagens have binding specificity for PAMPs rather than epitopes. Other defense collagens are expressed in humans, notably surfactant protein A and surfactant protein D. However, these will not be discussed as they are solely expressed in the lungs, do not activate complement, and function in opsonizing respiratory pathogens.

Mannose Binding Lectin. Mannose (or mannan) Binding Lectin belongs to the collectin family of proteins, defined by the presence of a lectin binding domain at the $\mathrm{C}$ terminal end of the protein. It is an acute phase soluble protein produced by hepatocytes, with a structure similar to that of $\mathrm{C} 1 \mathrm{q}$. The structure has an N-terminal Cysteine-rich domain, followed by a collagen domain possessing the common Gly-Xaa-Yaa amino acid repeat. At the C-terminus is the lectin binding domain, a structure shared with defense molecules isolated from mammals, amphibians, and plants [71]. The widespread distribution of these proteins in diverse species highlights a conserved evolutionary requirement for this protein. Indeed, absence of MBL in humans is associated with increased susceptibility to opportunistic infections [72,73]. MBL has binding specificity for patterns of mannose and $N$-aceytlglucosamine [74] associated with pathogen surfaces and apoptotic cells $[24,75,76]$. MBL possesses similar activity to the $\mathrm{C} 1 \mathrm{q}$ protein, resulting in cleavage of $\mathrm{C} 4$ and $\mathrm{C} 2$ following interactions with the MBL-associated serine proteases (MASPs) [77,78]. Cleavage is inhibited by C1q inhibitor [79]. Humans possess three MASPs, and another similar molecule, MAp19, which does not possess serine protease activity. They have structural similarity to $\mathrm{C} 1 \mathrm{~s}$, and cognate roles in activating the complement cascade. MASP-2 has substrate specificity for $\mathrm{C} 4$ and $\mathrm{C} 2$, resulting in generation of the $\mathrm{C} 3$ convertase $\mathrm{C} 4 \mathrm{~b} 2 \mathrm{a}$. It also has Factor Xa-like activity, cleaving pro-thrombin to thrombin and initiating the clotting pathway [79,80] MASP-1 cleaves $\mathrm{C} 2$, also contributing to complement activation [81]. In addition MASP-1 has been shown to have thrombin-like activity that results in cleavage of fibrinogen and Factor XIII [82,83]. MASP-1 also enhances inflammation by activation of the Protease Activated Receptor 4 (PAR4)-mediated NF- $\kappa$ B pathway and the p38 MAPK activation pathway in endothelial cells [84]. This results in production of pro-inflammatory cytokines, recruitment of leukocyte migration and adhesion. MASP-3 is an alternative splice transcript of MASP-1, possessing alternative specificity for the insulin-like growth factor binding protein 5 (IGFBP5) [85]. Its role in inflammation and clotting is still not clear. However, the activation of the clotting pathway has implications for deposition of fibrinogen in the site of infection, and may contribute to fibrosis, which is a hallmark of chronic HCV infection [86].

The gene encoding the MBL protein (MBL2) is known to possess polymorphisms that have a significant impact on oligomer formation and serum concentrations of the protein [87-91]. Early investigations of polymorphisms in the MBL2 gene in HCV infections associated underlying genetic differences with treatment outcome [92,93] and disease progression [94]. However, the role of MBL in $\mathrm{HCV}$ disease progression is not clear. Some studies have associated low serum levels of MBL to increased chance of liver fibrosis [95], while others demonstrated no effect of serum MBL concentration on HCV disease [96]. In contrast, others associated increased MBL and MASP-1 levels with pathogenesis [86]. Comparison between these studies is complicated by differences in population ethnicity, treatment status, and HCV genotype. Further studies of the activation of inflammation by MBL are required to demonstrate an association with $\mathrm{HCV}$ pathogenesis. 
A recent study demonstrated that MBL binds to the HCV surface glycoproteins E1 and E2, activating the complement pathway and also neutralizing entry of HCV into hepatoma cells in a similar way to antibodies [24]. This is consistent with the neutralizing activity of MBL observed against HIV-1 [23]. Dependent on the viral genotype, HCV E1 and E2 glycoproteins possess between 13 and 15 glycosylation sites that present mannose targets to MBL [97]. These glycosylation sites are proximal to receptor binding sites that are essential for HCV entry. As such, the neutralization of entry mediated by this lectin is consistent with the location of these mannose moieties. This suggests that clinical administration of MBL may be therapeutically useful against HCV infections. However, the pro-inflammatory nature of MBL-associated serine proteases would have to be taken into account when considering passive immunotherapy. Another clinical application for administration of MBL could be intervention during liver transplantation. Serum MBL levels are predictive of susceptibility to nosocomial infection during transplantation [98]. Passive administration could have the effect of reducing infection of a transplanted liver, while at the same time protecting against re-infection of the graft with HCV.

Ficolins. The family of ficolins share great structural similarity to the collectins, and play a similar role in innate immunity. Three human ficolins have been identified. M-ficolin (ficolin-1) is produced by macrophages in response to pro-inflammatory cytokines. L-ficolin (ficolin-2) and H-ficolin (ficolin-3, or Hakata antigen) are both expressed by hepatocytes [99]. They share a common overall structure, possessing a Cysteine-rich N-terminal domain, followed by a collagen repeat region. However, in contrast to MBL and C1q they possess a fibrinogen-like head region. The ficolin monomers associate to form higher-order oligomers with high avidity binding properties. All three molecules share binding specificity for acetylated compounds through interactions with the fibrinogen-like domain. Virus glycans often incorporate $N$-acetyl glucosamine (GlcNAc) moieties, which are recognized by ficolins [100]. Each of the glycans associated with the HCV glycoproteins contain a core $\mathrm{GlcNAc}_{2}$ moiety, and in vitro expression of these proteins has revealed that two of these glycans (N423 and N430) possess terminal GlcNAc residues [97]. It is still unclear if the glycoproteins incorporated into the virus particles possess these specific modifications. However, this hypothesis is supported by the finding that L-ficolin has specificity for the HCV E1 and E2 glycoproteins [39,101], resulting in neutralization of HCVpp and HCVcc [101], and contributing to activation of the complement cascade [39]. Expression of L-ficolin is also up-regulated in HCV-infected cells [39], suggesting that they might constitute a component of the acute phase response following infection. Polymorphisms in the promoter and coding regions of the ficolin proteins are associated with differential expression of L-ficolin [102], but less variability is observed in serum concentrations when compared to MBL. The indirect functions of ficolins are very similar to MBL. They bind to MASP-1 and MASP-2, triggering complement activation and cleavage of clotting factors in an identical way to MBL [103]. As such, they represent an additional innate PRR with a unique pattern of specificity, broadening the activation profile of the complement cascade. Further investigations are required to establish the role of ficolins in HCV infection. Interestingly, ficolins might be a component of the response that results in treatment induced clearance of infection. M-ficolin is one of only three genes that display up-regulated expression in individuals with the protective CC allele of the rs12979860 polymorphism in the IL28B promoter region [104]. This allele is associated with favorable treatment response and disease 
outcome [105]. This contrasted with lower expression of the pathway of interferon-stimulated genes in patients with this IL28B variant allele. It is plausible that increased M-ficolin expression represents a functional consequence of this polymorphism, resulting in enhanced neutralization, opsonization, or complement deposition required to suppress virus infection. However, further studies are required to extend these preliminary findings.

\section{Pentraxins}

Pentraxins are a conserved family of pattern recognition molecules produced in genetically diverse species, suggesting a strong selective advantage for these proteins. Members of this family share structural homology, with a conserved 200aa C-terminal pentraxin domain [106]. This diverse group includes the short pentraxins Serum Amyloid P (SAP) and C-reactive protein (CRP), and the long pentraxins exemplified by PTX3. Short pentraxins are acute phase proteins produced in the liver [107], while long pentraxins are expressed by dendritic cells in response to activation of TLR signaling pathways [108]. Despite structural differences, all pentraxins are pentameric protein structures with calcium-dependent binding to lipoproteins, as well as calcium-independent binding to other ligands. CRP is an acute phase protein that is produced by hepatocytes in response to IL-6. It activates complement $\mathrm{Clq}$ in the presence of phosphocholine, produced by apoptotic cells and present in the capsule of some bacterial species. Although it is believed not to be involved in direct recognition of viruses, CRP has been implicated in mixed cryoglobulinemia associated with HCV infection [109]. More relevant to protection against virus infections is the prototype long pentraxin PTX3 [110]. It has diverse binding interactions, including host proteins, bacteria, and virus glycoproteins [111,112]. Like CRP, PTX3 also binds to the globular head domain of complement C1q. This interaction augments complement activation when PTX3 is immobilized [113], but inhibits antibody interactions with C1q when in solution. This suggests that PTX3 binding to virus glycoproteins might provide an additional mechanism by which complement can be deposited on viruses and infected cells, enhancing deposition of $\mathrm{C} 1 \mathrm{q}$ and $\mathrm{C} 3 \mathrm{~b}$ on apoptotic cell surfaces. PTX3 is a rapid acute phase protein. Expression is immediately up-regulated following infection or inflammation [114]. PTX3 is recruited to the synapse between dendritic cells and apoptotic cells. This results in modulation of antigen presentation pathways in the DC, reducing the cell's cross-presentation of $\mathrm{HCV}$ antigens to $\mathrm{CD}^{+} \mathrm{T}$ cells [115]. It remains to be determined if this pattern recognition molecule has a role in the immune response to $\mathrm{HCV}$ infection.

\section{Lipoproteins}

There is an emerging role for lipoproteins in innate immunity. Serum Amyloid A1 (SAA-1) and Serum Amyloid A2 (SAA-2) are acute phase lipoproteins rapidly produced in the liver following trauma or infection, or following stimulation by the inflammatory cytokines IL-6 and TNF $\alpha$ [116,117]. The SAA proteins potently enhance cytokine production from peripheral blood mononuclear cells [118], promoting inflammation. In HIV-1 infection, SAA production occurs significantly before detection of viral RNA [17], suggesting that this may have a significant role in limiting the initial viral burst of replication. As well as its role in acute phase inflammation, SAA plays a physiological role in transport of cholesterol mediated by Scavenger Receptor B1 (SR-B1) [119-121]. SAA circulates as 
complexes with high-density lipoprotein (HDL) and causes remodeling of HDL in acute phase inflammation. As such, SAA may play a unique and intriguing role in preventing HCV infection. SR-B1 and HDL are implicated in the entry pathway of HCV. SR-B1 binding of virions is essential in the early steps of HCV entry [122-125], and this entry is augmented by binding of HDL [126-128]. SAA inhibits HCV entry by binding to virus particles $[129,130]$, and this interaction is inhibited by the presence of HDL [129]. Together these findings suggest that SAA binds to HCV lipo-viral particles (LVP) consisting of lipoproteins and the HCV virion, blocking the interaction between LVPs and SRB1. In this model, HDL is able to strip away SAA from particles and enhance entry of the virus into hepatocytes. It is unclear if this anti-viral pathway has in vivo efficacy. Studies of the circulating SAA concentrations in chronic HCV infection have shown slightly increased levels [129], or no difference to normal controls [131]. This contrasts with acute viral infections, and is consistent with the observation that SAA is produced only in the early stages of acute infection [131].

In addition to SAA, high-density lipoproteins may also have a role in innate immunity. Along with the major role of HDL in promoting cholesterol efflux from peripheral tissues and recovery in hepatocytes, HDL modulates activation of the complement cascade, as well as influencing expression of PTX3 [132]. This implicates HDL in orchestrating innate immunity in the liver, modulating the action of soluble innate factors.

\section{Defensins}

Humans express two types of defensins, $\alpha$-defensins (human neutrophil peptides HNP1-4, HD5 and HD6), and $\beta$-defensins (hBD1-4). Both types of defensin are short (20-40 amino acids) soluble, charged peptides with anti-microbial properties [133,134]. The $\alpha$-defensins possess anti-viral activity, blocking virus entry and replication [25,135], as well as modulating complement activation by C1q [136]. They act by inserting into membranes, destabilizing virus particles and recruiting macrophages and enhancing phagocytosis. The $\beta$-defensins play a similar role in antiviral defense, binding to virions and preventing entry [23]. hBD-1 is constitutively expressed by most cell types, but expression can be up-regulated in plasmacytoid dendritic cells (pDCs) and monocytes in reaction to virus infections [137]. In contrast, hBD2 is an acute phase protein produced by pDCs, monocytes, and epithelial cells in response to inflammatory cytokines and the presence of virus infection [138]. hBD2 can bind C1q resulting in complement deposition [139]. hBD have been implicated in protection against HIV-1 infection in serially exposed uninfected individuals [140]. Despite the broad range of anti-viral activity observed for defensins [141] there is a paucity of research investigating the role of defensins in $\mathrm{HCV}$ infection. The $\alpha$-defensins are produced in chronic $\mathrm{HCV}$ infection, and correlate with liver fibrosis [142]. However, it is unclear if binding of these peptides to virus particles inhibits infection in vitro or in vivo.

\section{Evasion of Immune Responses}

HCV utilizes a number of mechanisms to evade host defenses, including elements of the humoral innate immune system (Table 1). The majority of virions circulate in the blood associated with lipoproteins [143,144], forming a lipo-viral particle [145]. This complex includes the HCV virion, and low density lipoproteins containing apolipoproteins E, C1 and B [146,147]. These associations are 
mediated by the HCV-encoded glycoproteins and are intimately related to resistance to antibody neutralization [148,149]. HCV virions are also extensively glycosylated, which is believed to reduce the immunogenicity of the envelope glycoproteins and contribute to evasion of recognition by neutralizing antibodies [150,151]. Additionally, three hypervariable regions in the E2 protein [152] tolerate extensive genetic heterogeneity and act as immune 'decoys', possessing immunodominant epitopes to which antibodies are rapidly produced [153]. Despite these evasion mechanisms, targets for innate immunity remain conserved; the glycosylation motifs that are essential for HCV biogenesis represent a target for defense collagens. Many of these glycans are conserved between functional isolates representing all HCV genotypes [152]. If these innate binding proteins have a neutralizing effect on virus replication, mutants escaping recognition would be expected to be preferentially selected. To date, defense collagen-resistant HCV strains have not been described. Some glycosylation sites in the envelope glycoproteins do vary between isolates, suggesting at least some plasticity in the glycosylation surrounding virus particles. There is evidence from pandemic H1N1 influenza viruses that supports the proposition that defense collagens apply selection pressure on virus populations [154]. It is plausible that other innate immune proteins apply selective pressure on the viral population in the early stages of infection following transmission. Longitudinal analysis of the susceptibility of $\mathrm{HCV}$ isolates to recognition by innate proteins will reveal if this is a biologically relevant effect. There is evidence of evasion of other innate humoral proteins, especially the complement cascade. The incorporation of CD59 into HCV virions suggests that HCV has evolved to resist deposition of the membrane attack complex onto virions [64]. The inhibition of $\mathrm{C} 4$ production by HCV core and NS5A proteins also provides evidence that there is a selective advantage to disabling the complement cascade [63]. A novel, yet undescribed result of the association of virions with lipoproteins may be the prevention of Serum Amyloid A binding to the virus, preventing the inhibitory effects of this innate protein.

Table 1. Hepatitis C Virus (HCV) interactions with components of the humoral innate immune system and possible escape from innate immune recognition.

\begin{tabular}{|l|l|l|l|}
\hline Component & Function & HCV Escape Mechanism & Reference(s) \\
\hline Complement C4 & $\begin{array}{l}\text { Key mediator of } \\
\text { opsonisation, direct lysis, } \\
\text { and inflammation }\end{array}$ & $\begin{array}{l}\text { Core and NS5a proteins inhibit } \\
\text { transcription of C4 }\end{array}$ & {$[63]$} \\
\hline Complement C5-9 & $\begin{array}{l}\text { Generation of the } \\
\text { membrane attack } \\
\text { complex }\end{array}$ & $\begin{array}{l}\text { Incorporation of CD59 into HCV } \\
\text { virions }\end{array}$ & {$[62]$} \\
\hline gC1q-R & $\begin{array}{l}\text { Enhanced chemotaxis } \\
\text { and phagocytosis; } \\
\text { decreased activation of } \\
\text { B- and T cells }\end{array}$ & $\begin{array}{l}\text { Core interacts with gC1q-R, } \\
\text { suppressing T cell activation }\end{array}$ & {$[70]$} \\
\hline $\begin{array}{l}\text { Defense collagens (MBL; } \\
\text { Ficolins) }\end{array}$ & $\begin{array}{l}\text { Recognition of } \\
\text { glycoproteins }\end{array}$ & $\begin{array}{l}\text { HCV glycoproteins have differential } \\
\text { glycosylation patterns; association } \\
\text { with lipoproteins may block access of } \\
\text { defense collagens }\end{array}$ & {$[152] ;[145]$} \\
\hline Serum Amyloid A (SAA) & $\begin{array}{l}\text { Binding to glycoproteins, } \\
\text { inhibiting entry }\end{array}$ & $\begin{array}{l}\text { Interaction with High-density } \\
\text { lipoprotein (HDL)/SR-B1 prevents } \\
\text { SAA binding? }\end{array}$ & \\
\hline
\end{tabular}




\section{Role of Innate Immunity in Pathogenesis of HCV Infection}

So far we have established that the humoral innate immune system contributes to immunity against viral pathogens, including $\mathrm{HCV}$. However, these same proteins can contribute to the pathology of HCV disease [155]. Innate immunity is broadly implicated in liver fibrosis in chronic HCV infection, and initiation of cryoglobulinemia that is associated with $40 \%$ of HCV infections. Liver fibrosis is caused by the accumulation of extracellular matrix in the liver, particularly collagen. This deposition of fibrotic material is mediated by stellate cells, portal fibroblasts and myofibroblasts (reviewed in [156]). In HCV infection, fibrosis severity correlates with activation of stellate cells [157], which can be activated by cleavage of Protease Activated Receptors by thrombin $[158,159]$. This implicates MBL-associated serine proteases in stellate cell activation. Indeed, activity of MBL/MASP-1 complexes is positively associated with developing fibrosis [86,95,160,161].

Another pathology specifically associated with innate immunity in HCV infection is the accumulation of autoantibodies, resulting in cryoglobulinemia [162]. These antibodies are directed to a range of host proteins, including immunoglobulins [163], cardiolipin [164], and members of the soluble innate immune proteins. Despite there being no evidence for CRP interactions with HCV, autoantibodies to CRP are produced in HCV infection, related to cryoglobulinemia [109]. Antibodies to $\mathrm{C} 1 \mathrm{q}$ are observed in up to $38 \%$ of $\mathrm{HCV}$ infections [165]. The production of autoantibodies that react with C1q results in vascular damage [166], a pathology associated with mixed cryoglobulinemia. $\mathrm{HCV}$-associated cryoglobulinemic glomerulonephritis is also associated with autoantibodies to the C1q and C4d molecules [167], as well as MBL and MASP [168]. Autoantibody production might be a consequence of the interaction between HCV E2 protein and CD81 on the surface of B lymphocytes. This interaction is known to reduce the activation threshold and promote hypermutation of the immunoglobulin gene $[169,170]$, indicating a mechanism for autoantibody production.

The complement receptor gC1q-R may have an extremely important role in resolution of infection. $\mathrm{HCV}$ core protein interactions with $\mathrm{gClq}-\mathrm{R}$ can cause pathogenic effects in vivo. In chimpanzees, expression of this receptor on the surface of T-cells correlated with reduced capacity for activation and proliferation, suggesting that the core interaction inhibits $T$ cell activation [171,172]. Circulating $\mathrm{gClq}-\mathrm{R}$ has also been implicated in mixed cryoglobulinemia. This soluble form of the receptor is caused by dysregulation of $\mathrm{gClq}-\mathrm{R}$ shedding following interaction with core protein. The receptor circulates as a complex with core, sequestering the $\mathrm{C} 4 \mathrm{~d}$ cleavage product to vascular tissue and causing complement mediated lysis [166].

\section{Contribution of Innate Immunity to HCV Vaccination and Therapy}

Designing vaccines to highly mutable RNA viruses poses a significant challenge. It is likely that activation of broad $\mathrm{T}$ cell responses, and potently neutralizing antibodies will be required for suppression of viral replication and clearance. However, optimizing antigen recognition by innate immunity is essential to induce the optimal adaptive immune response. Vaccine induced immunity is regulated by stimulation of innate immune factors such as complement and the defense collagens. These innate molecules provide co-stimulatory signals that are required for the generation of protective immune memory. Greater understanding of innate immune modulation will yield directed vaccines 
synthesised to optimize production of adaptive immunity. The evidence supporting the role of $\mathrm{HCV}$ proteins in inhibiting many aspects of innate immunity informs the search for important innate factors. Controlling gene transcription to alter the serum concentration of these humoral proteins might improve vaccine efficacy. There is evidence that complement components have a role in regulating activation of $\mathrm{B}$ cells and $\mathrm{T}$ cells [173-175]. They also augment antibody neutralization [60], and can directly neutralize virus infectivity [176]. This is likely to be the case for additional PRRs that modulate complement activation. These properties might also prove useful in augmentation of therapies by passive administration of soluble PRRs. Direct neutralization of virus particles and indirect immune activation are both desirable qualities. However, given the role of these molecules in activating stellate cells, therapeutic forms of these proteins might need modification to retain anti-viral properties, while preventing collagen deposition. Synthetic, recombinant forms of these lectins have recently been used to improve ligand affinity and activity [177]. Similar modifications might develop therapeutically useful molecules.

\section{Concluding Remarks and Future Perspectives}

There is an emerging role for soluble innate immune proteins in contributing to neutralization of $\mathrm{HCV}$ infection and clearance of $\mathrm{HCV}$ infected cells. There is evidence that pattern recognition molecules such as MBL, serum ficolins and lipoproteins all contribute to recognition of virus infections. This leads to activation of complement pathways, resulting in specific lysis of virions, opsonization of viruses and increased phagocytosis, and direct neutralization of virus particles. The importance of this anti-viral response is highlighted by modulation of key complement components by $\mathrm{HCV}$-encoded proteins. However, there is still little known about the interplay between HCV and the complement cascade.

The neutralizing effect of these innate molecules is an under-appreciated phenomenon. Many studies of serum neutralization do not account for the presence of these proteins. There are no studies of the dynamics of acute-phase proteins in early HCV infection, and many reports of serum neutralization of $\mathrm{HCV}$ entry consider antibodies as sole mediators of neutralization [11,14-16]. Studies using fractionated serum resolve the potential for multi-factorial neutralization in $\mathrm{HCV}$ infections [178,179]. Greater understanding of the dynamics of pattern recognition receptors and neutralizing antibodies will define the relative contributions of these two interrelated immune effectors.

Little is known about the evolution of $\mathrm{HCV}$ in response to PRRs. Although there is evidence that other RNA viruses escape recognition by collectins, there is little evidence of selection of PRR-refractive HCV isolates, either in vitro or in vivo. It is possible that the emerging quasi-species following transmission of $\mathrm{HCV}$ is shaped by the surveillance PRRs and the acute-phase proteins that are produced immediately following infection. This would make PRRs important therapeutic interventions that might prevent establishment of acute phase viraemia and development of chronic infections. Although under-studied, innate immunity has great potential as a target for the development of novel anti-HCV therapies.

\section{Conflict of interest}

The authors declare no conflict of interest. 


\section{Acknowledgements}

The authors are supported by the Medical Research Council (G0801169), the European Union (MRTN-CT-2006-035599) and the Nottingham Digestive Disease Centre Biomedical Research Unit. We thank Dr Richard Brown for critical assessment of the manuscript.

\section{References and Notes}

1. Hoofnagle, J.H. Hepatitis C: The clinical spectrum of disease. Hepatology 1997, 26, 15S-20S.

2. Isaguliants, M.G.; Ozeretskovskaya, N.N. Host background factors contributing to hepatitis C virus clearance. Curr. Pharm. Biotechnol. 2003, 4, 185-193.

3. Major, M.E.; Dahari, H.; Mihalik, K.; Puig, M.; Rice, C.M.; Neumann, A.U.; Feinstone, S.M. Hepatitis $\mathrm{C}$ virus kinetics and host responses associated with disease and outcome of infection in chimpanzees. Hepatology 2004, 39, 1709-1720.

4. Cooper, S.; Erickson, A.L.; Adams, E.J.; Kansopon, J.; Weiner, A.J.; Chien, D.Y.; Houghton, M.; Parham, P.; Walker, C.M. Analysis of a successful immune response against hepatitis $\mathrm{C}$ virus. Immunity 1999, 10, 439-449.

5. Missale, G.; Bertoni, R.; Lamonaca, V.; Valli, A.; Massari, M.; Mori, C.; Rumi, M.G.; Houghton, M.; Fiaccadori, F.; Ferrari, C. Different clinical behaviors of acute hepatitis $\mathrm{C}$ virus infection are associated with different vigor of the anti-viral cell-mediated immune response. J. Clin. Investig. 1996, 98, 706-714.

6. Pawlotsky, J.M. Diagnostic tests for hepatitis C. J. Hepatol. 1999, 31, 71-79.

7. Thimme, R.; Oldach, D.; Chang, K.M.; Steiger, C.; Ray, S.C.; Chisari, F.V. Determinants of viral clearance and persistence during acute hepatitis C virus infection. J. Exp. Med. 2001, 194, 1395-1406.

8. Thimme, R.; Bukh, J.; Spangenberg, H.C.; Wieland, S.; Pemberton, J.; Steiger, C.; Govindarajan, S.; Purcell, R.H.; Chisari, F.V. Viral and immunological determinants of hepatitis C virus clearance, persistence, and disease. Proc. Natl. Acad. Sci. U. S. A. 2002, 99, 15661-15668.

9. Pape, G.R.; Gerlach, T.J.; Diepolder, H.M.; Gruner, N.; Jung, M.; Santantonio, T. Role of the specific T-cell response for clearance and control of hepatitis C virus. J. Viral. Hepat. 1999, 6, 36-40.

10. Ishii, K.; Rosa, D.; Watanabe, Y.; Katayama, T.; Harada, H.; Wyatt, C.; Kiyosawa, K.; Aizaki, H.; Matsuura, Y.; Houghton, M.; et al. High titers of antibodies inhibiting the binding of envelope to human cells correlate with natural resolution of chronic hepatitis C. Hepatology 1998, 28, $1117-1120$.

11. Pestka, J.M.; Zeisel, M.B.; Blaser, E.; Schurmann, P.; Bartosch, B.; Cosset, F.L.; Patel, A.H.; Meisel, H.; Baumert, J.; Viazov, S.; et al. Rapid induction of virus-neutralizing antibodies and viral clearance in a single-source outbreak of hepatitis C. Proc. Natl. Acad. Sci. U. S. A. 2007, 104, 6025-6030.

12. Orland, J.R.; Wright, T.L.; Cooper, S. Acute hepatitis C. Hepatology 2001, 33, 321-327.

13. Spada, E.; Mele, A.; Berton, A.; Ruggeri, L.; Ferrigno, L.; Garbuglia, A.R.; Perrone, M.P.; Girelli, G.; Del Porto, P.; Piccolella, E.; et al. Multispecific T cell response and negative HCV RNA tests during acute $\mathrm{HCV}$ infection are early prognostic factors of spontaneous clearance. Gut 2004, 53, $1673-1681$. 
14. Netski, D.M.; Mosbruger, T.; Depla, E.; Maertens, G.; Ray, S.C.; Hamilton, R.G.; Roundtree, S.; Thomas, D.L.; McKeating, J.; Cox, A. Humoral immune response in acute hepatitis $\mathrm{C}$ virus infection. Clin. Infect. Dis. 2005, 41, 667-675.

15. Dowd, K.A.; Netski, D.M.; Wang, X.H.; Cox, A.L.; Ray, S.C. Selection pressure from neutralizing antibodies drives sequence evolution during acute infection with hepatitis $\mathrm{C}$ virus. Gastroenterology 2009, 136, 2377-2386.

16. Logvinoff, C.; Major, M.E.; Oldach, D.; Heyward, S.; Talal, A.; Balfe, P.; Feinstone, S.M.; Alter, H.; Rice, C.M.; McKeating, J.A. Neutralizing antibody response during acute and chronic hepatitis C virus infection. Proc. Natl. Acad. Sci. U. S. A. 2004, 101, 10149-10154.

17. Kramer, H.B.; Lavender, K.J.; Qin, L.; Stacey, A.R.; Liu, M.K.; di Gleria, K.; Simmons, A.; Gasper-Smith, N.; Haynes, B.F.; McMichael, A.J.; et al. Elevation of intact and proteolytic fragments of acute phase proteins constitutes the earliest systemic antiviral response in HIV-1 infection. PLoS Pathog. 2010, 6, e1000893.

18. Barth, H.; Rybczynska, J.; Patient, R.; Choi, Y.; Sapp, R.K.; Baumert, T.F.; Krawczynski, K.; Liang, T.J. Both innate and adaptive immunity mediate protective immunity against hepatitis $\mathrm{C}$ virus infection in chimpanzees. Hepatology 2011, 54, 1135-1148.

19. Crozat, K.; Georgel, P. Identification of mouse cytomegalovirus resistance loci by ENU mutagenesis. Viruses 2009, 1, 460-483.

20. Crozat, K.; Vivier, E.; Dalod, M. Crosstalk between components of the innate immune system: Promoting anti-microbial defenses and avoiding immunopathologies. Immunol. Rev. 2009, 227, 129-149.

21. Major, M.E.; Mihalik, K.; Puig, M.; Rehermann, B.; Nascimbeni, M.; Rice, C.M.; Feinstone, S.M. Previously infected and recovered chimpanzees exhibit rapid responses that control hepatitis $\mathrm{C}$ virus replication upon rechallenge. J. Virol. 2002, 76, 6586-6595.

22. Su, A.I.; Pezacki, J.P.; Wodicka, L.; Brideau, A.D.; Supekova, L.; Thimme, R.; Wieland, S.; Bukh, J.; Purcell, R.H.; Schultz, P.G.; et al. Genomic analysis of the host response to hepatitis C virus infection. Proc. Natl. Acad. Sci. U. S. A. 2002, 99, 15669-15674.

23. Leikina, E.; Delanoe-Ayari, H.; Melikov, K.; Cho, M.S.; Chen, A.; Waring, A.J.; Wang, W.; Xie, Y.; Loo, J.A.; Lehrer, R.I.; et al. Carbohydrate-binding molecules inhibit viral fusion and entry by cross-linking membrane glycoproteins. Nat. Immunol. 2005, 6, 995-1001.

24. Brown, K.S.; Keogh, M.J.; Owsianka, A.M.; Adair, R.; Patel, A.H.; Arnold, J.N.; Ball, J.K.; Sim, R.B.; Tarr, A.W.; Hickling, T.P. Specific interaction of hepatitis C virus glycoproteins with mannan binding lectin inhibits virus entry. Protein Cell 2010, 1, 664-674.

25. Buck, C.B.; Day, P.M.; Thompson, C.D.; Lubkowski, J.; Lu, W.; Lowy, D.R.; Schiller, J.T. Human alpha-defensins block papillomavirus infection. Proc. Natl. Acad. Sci. U. S. A. 2006, 103, $1516-1521$.

26. Iwasaki, A.; Medzhitov, R. Regulation of adaptive immunity by the innate immune system. Science 2010, 327, 291-295.

27. Leibundgut-Landmann, S.; Osorio, F.; Brown, G.D.; Reis e Sousa, C. Stimulation of dendritic cells via the dectin-1/syk pathway allows priming of cytotoxic T-cell responses. Blood 2008, 112, 4971-4980. 
28. Liu, S.; Wu, J.; Zhang, T.; Qian, B.; Wu, P.; Li, L.; Yu, Y.; Cao, X. Complement C1q chemoattracts human dendritic cells and enhances migration of mature dendritic cells to CCL19 via activation of AKT and MAPK pathways. Mol. Immunol. 2008, 46, 242-249.

29. Joffre, O.; Nolte, M.A.; Sporri, R.; Reis e Sousa, C. Inflammatory signals in dendritic cell activation and the induction of adaptive immunity. Immunol. Rev. 2009, 227, 234-247.

30. Avirutnan, P.; Mehlhop, E.; Diamond, M.S. Complement and its role in protection and pathogenesis of Flavivirus infections. Vaccine 2008, 26, I100-I107.

31. Fitzgerald-Bocarsly, P.; Feng, D. The role of type I interferon production by dendritic cells in host defense. Biochimie 2007, 89, 843-855.

32. Newman, K.C.; Riley, E.M. Whatever turns you on: Accessory-cell-dependent activation of NK cells by pathogens. Nat. Rev. Immunol. 2007, 7, 279-291.

33. Moretta, A.; Marcenaro, E.; Parolini, S.; Ferlazzo, G.; Moretta, L. NK cells at the interface between innate and adaptive immunity. Cell Death Differ. 2008, 15, 226-233.

34. Belz, G.; Mount, A.; Masson, F. Dendritic cells in viral infections. Handb. Exp. Pharmacol. 2009, 51-77.

35. Perrin-Cocon, L.A.; Villiers, C.L.; Salamero, J.; Gabert, F.; Marche, P.N. B cell receptors and complement receptors target the antigen to distinct intracellular compartments. J. Immunol. 2004, 172, 3564-3572.

36. Cretin, F.C.; Serra, V.A.; Villiers, M.B.; Laharie, A.M.; Marche, P.N.; Gabert, F.M. C3b complexation diversifies naturally processed T cell epitopes. Mol. Immunol. 2007, 44, 2893-2899.

37. Barrionuevo, P.; Beigier-Bompadre, M.; Ilarregui, J.M.; Toscano, M.A.; Bianco, G.A.; Isturiz, M.A.; Rabinovich, G.A. A novel function for galectin-1 at the crossroad of innate and adaptive immunity: Galectin-1 regulates monocyte/macrophage physiology through a nonapoptotic ERK-dependent pathway. J. Immunol. 2007, 178, 436-445.

38. Bayry, J.; Lacroix-Desmazes, S.; Kazatchkine, M.D.; Hermine, O.; Tough, D.F.; Kaveri, S.V. Modulation of dendritic cell maturation and function by B lymphocytes. J. Immunol. 2005, 175, $15-20$.

39. Liu, J.; Ali, M.A.; Shi, Y.; Zhao, Y.; Luo, F.; Yu, J.; Xiang, T.; Tang, J.; Li, D.; Hu, Q.; et al. Specifically binding of L-ficolin to N-glycans of HCV envelope glycoproteins E1 and E2 leads to complement activation. Cell Mol. Immunol. 2009, 6, 235-244.

40. Dolganiuc, A.; Kodys, K.; Kopasz, A.; Marshall, C.; Do, T.; Romics, L., Jr.; Mandrekar, P.; Zapp, M.; Szabo, G. Hepatitis C virus core and nonstructural protein 3 proteins induce pro- and anti-inflammatory cytokines and inhibit dendritic cell differentiation. J. Immunol. 2003, 170, 5615-5624.

41. Lozach, P.Y.; Lortat-Jacob, H.; de Lacroix de Lavalette, A.; Staropoli, I.; Foung, S.; Amara, A.; Houles, C.; Fieschi, F.; Schwartz, O.; Virelizier, J.L.; et al. DC-sign and L-sign are high affinity binding receptors for hepatitis C virus glycoprotein E2. J. Biol. Chem. 2003, 278, 20358-20366.

42. Barth, H.; Ulsenheimer, A.; Pape, G.R.; Diepolder, H.M.; Hoffmann, M.; Neumann-Haefelin, C.; Thimme, R.; Henneke, P.; Klein, R.; Paranhos-Baccala, G.; et al. Uptake and presentation of hepatitis C virus-like particles by human dendritic cells. Blood 2005, 105, 3605-3614. 
43. Yamada, E.; Montoya, M.; Schuettler, C.G.; Hickling, T.P.; Tarr, A.W.; Vitelli, A.; Dubuisson, J.; Patel, A.H.; Ball, J.K.; Borrow, P. Analysis of the binding of hepatitis C virus genotype $1 \mathrm{a}$ and $1 \mathrm{~b}$ E2 glycoproteins to peripheral blood mononuclear cell subsets. J. Gen. Virol. 2005, 86, 2507-2512.

44. Zhou, Y.; Lukes, Y.; Anderson, J.; Fileta, B.; Reinhardt, B.; Sjogren, M. Hepatitis C virus E2 envelope protein induces dendritic cell maturation. J. Viral. Hepat. 2007, 14, 849-858.

45. Barth, H.; Schnober, E.K.; Neumann-Haefelin, C.; Thumann, C.; Zeisel, M.B.; Diepolder, H.M.; Hu, Z.; Liang, T.J.; Blum, H.E.; Thimme, R.; et al. Scavenger receptor class B is required for hepatitis $\mathrm{C}$ virus uptake and cross-presentation by human dendritic cells. J. Virol. 2008, 82, 3466-3479.

46. Moshage, H. Cytokines and the hepatic acute phase response. J. Pathol. 1997, 181, 257-266.

47. Gerencer, M.; Burek, V.; Crowe, B.A.; Barrett, N.P.; Dorner, F. The role of complement and gp120-specific antibodies in virus lysis and CD4+ T cell depletion in HIV-1-infected patients. Microb. Pathog. 1998, 25, 253-266.

48. Sullivan, B.L.; Knopoff, E.J.; Saifuddin, M.; Takefman, D.M.; Saarloos, M.N.; Sha, B.E.; Spear, G.T. Susceptibility of HIV-1 plasma virus to complement-mediated lysis. Evidence for a role in clearance of virus in vivo. J. Immunol. 1996, 157, 1791-1798.

49. Terajima, M.; Cruz, J.; Co, M.D.; Lee, J.H.; Kaur, K.; Wilson, P.C.; Ennis, F.A. Complementdependent lysis of influenza A virus-infected cells by broadly cross-reactive human monoclonal antibodies. J. Virol. 2011, 85, 13463-13467.

50. Hezareh, M.; Hessell, A.J.; Jensen, R.C.; van de Winkel, J.G.; Parren, P.W. Effector function activities of a panel of mutants of a broadly neutralizing antibody against human immunodeficiency virus type 1. J. Virol. 2001, 75, 12161-12168.

51. Gal, P.; Barna, L.; Kocsis, A.; Zavodszky, P. Serine proteases of the classical and lectin pathways: similarities and differences. Immunobiology 2007, 212, 267-277.

52. Ikeda, F.; Haraguchi, Y.; Jinno, A.; Iino, Y.; Morishita, Y.; Shiraki, H.; Hoshino, H. Human complement component C1q inhibits the infectivity of cell-free HTLV-I. J. Immunol. 1998, 161, 5712-5719.

53. Ebenbichler, C.F.; Thielens, N.M.; Vornhagen, R.; Marschang, P.; Arlaud, G.J.; Dierich, M.P. Human immunodeficiency virus type 1 activates the classical pathway of complement by direct $\mathrm{C} 1$ binding through specific sites in the transmembrane glycoprotein gp41. J. Exp. Med. 1991, 174, 1417-1424.

54. Rus, H.; Cudrici, C.; Niculescu, F. The role of the complement system in innate immunity. Immunol. Res. 2005, 33, 103-112.

55. Lambris, J.D.; Muller-Eberhard, H.J. The multifunctional role of C3: Structural analysis of its interactions with physiological ligands. Mol. Immunol. 1986, 23, 1237-1242.

56. Francis, K.; Lewis, B.M.; Akatsu, H.; Monk, P.N.; Cain, S.A.; Scanlon, M.F.; Morgan, B.P.; Ham, J.; Gasque, P. Complement C3a receptors in the pituitary gland: A novel pathway by which an innate immune molecule releases hormones involved in the control of inflammation. FASEB J. 2003, 17, 2266-2268. 
57. Mehlhop, E.; Whitby, K.; Oliphant, T.; Marri, A.; Engle, M.; Diamond, M.S. Complement activation is required for induction of a protective antibody response against West Nile virus infection. J. Virol. 2005, 79, 7466-7477.

58. Mehlhop, E.; Fuchs, A.; Engle, M.; Diamond, M.S. Complement modulates pathogenesis and antibody-dependent neutralization of West Nile virus infection through a C5-independent mechanism. Virology 2009, 393, 11-15.

59. Fuchs, A.; Pinto, A.K.; Schwaeble, W.J.; Diamond, M.S. The lectin pathway of complement activation contributes to protection from West Nile virus infection. Virology 2011, 412, 101-109.

60. Mehlhop, E.; Nelson, S.; Jost, C.A.; Gorlatov, S.; Johnson, S.; Fremont, D.H.; Diamond, M.S.; Pierson, T.C. Complement protein $\mathrm{Clq}$ reduces the stoichiometric threshold for antibodymediated neutralization of West Nile virus. Cell Host Microbe 2009, 6, 381-391.

61. Meyer, K.; Basu, A.; Przysiecki, C.T.; Lagging, L.M.; Di Bisceglie, A.M.; Conley, A.J.; Ray, R. Complement-mediated enhancement of antibody function for neutralization of pseudotype virus containing hepatitis C virus E2 chimeric glycoprotein. J. Virol. 2002, 76, 2150-2158.

62. Dumestre-Perard, C.; Ponard, D.; Drouet, C.; Leroy, V.; Zarski, J.P.; Dutertre, N.; Colomb, M.G. Complement $\mathrm{C} 4$ monitoring in the follow-up of chronic hepatitis $\mathrm{C}$ treatment. Clin. Exp. Immunol. 2002, 127, 131-136.

63. Banerjee, A.; Mazumdar, B.; Meyer, K.; Di Bisceglie, A.M.; Ray, R.B.; Ray, R. Transcriptional repression of $\mathrm{C} 4$ complement by hepatitis $\mathrm{C}$ virus proteins. J. Virol. 2011, 85, 4157-4166.

64. Amet, T.; Ghabril, M.; Chalasani, N.; Byrd, D.; Hu, N.; Grantham, A.; Liu, Z.; Qin, X.; He, J.J.; $\mathrm{Yu}, \mathrm{Q}$. CD59 incorporation protects hepatitis $\mathrm{C}$ virus against complement-mediated destruction. Hepatology 2011, doi:10.1002/hep.24686.

65. Vanderplasschen, A.; Mathew, E.; Hollinshead, M.; Sim, R.B.; Smith, G.L. Extracellular enveloped vaccinia virus is resistant to complement because of incorporation of host complement control proteins into its envelope. Proc. Natl. Acad. Sci. U. S. A. 1998, 95, 7544-7549.

66. Spear, G.T.; Lurain, N.S.; Parker, C.J.; Ghassemi, M.; Payne, G.H.; Saifuddin, M. Host cell-derived complement control proteins CD55 and CD59 are incorporated into the virions of two unrelated enveloped viruses. Human T cell leukemia/lymphoma virus type I (HTLV-I) and human cytomegalovirus (HCMV). J. Immunol. 1995, 155, 4376-4381.

67. Marschang, P.; Sodroski, J.; Wurzner, R.; Dierich, M.P. Decay-accelerating factor (CD55) protects human immunodeficiency virus type 1 from inactivation by human complement. Eur. J. Immunol. 1995, 25, 285-290.

68. Ghebrehiwet, B.; Lim, B.L.; Peerschke, E.I.; Willis, A.C.; Reid, K.B. Isolation, CDNA cloning, and overexpression of a 33-kd cell surface glycoprotein that binds to the globular "Heads" Of C1q. J. Exp. Med. 1994, 179, 1809-1821.

69. Ghebrehiwet, B.; Lim, B.L.; Kumar, R.; Feng, X.; Peerschke, E.I. gC1q-R/p33, a member of a new class of multifunctional and multicompartmental cellular proteins, is involved in inflammation and infection. Immunol. Rev. 2001, 180, 65-77.

70. Saadoun, D.; Sadallah, S.; Trendelenburg, M.; Limal, N.; Sene, D.; Piette, J.C.; Schifferli, J.A.; Cacoub, P. Anti-C1q antibodies in hepatitis C virus infection. Clin. Exp. Immunol. 2006, 145, 308-312. 
71. Hansen, S.; Holmskov, U. Structural aspects of collectins and receptors for collectins. Immunobiology 1998, 199, 165-189.

72. Summerfield, J.A.; Ryder, S.; Sumiya, M.; Thursz, M.; Gorchein, A.; Monteil, M.A.; Turner, M.W. Mannose binding protein gene mutations associated with unusual and severe infections in adults. Lancet 1995, 345, 886-889.

73. Hibberd, M.L.; Sumiya, M.; Summerfield, J.A.; Booy, R.; Levin, M. Association of variants of the gene for mannose-binding lectin with susceptibility to meningococcal disease. Meningococcal research group. Lancet 1999, 353, 1049-1053.

74. Ikeda, K.; Sannoh, T.; Kawasaki, N.; Kawasaki, T.; Yamashina, I. Serum lectin with known structure activates complement through the classical pathway. J. Biol. Chem. 1987, 262, 7451-7454.

75. Ogden, C.A.; deCathelineau, A.; Hoffmann, P.R.; Bratton, D.; Ghebrehiwet, B.; Fadok, V.A.; Henson, P.M. C1q and mannose binding lectin engagement of cell surface calreticulin and CD91 initiates macropinocytosis and uptake of apoptotic cells. J. Exp. Med. 2001, 194, 781-795.

76. Nauta, A.J.; Raaschou-Jensen, N.; Roos, A.; Daha, M.R.; Madsen, H.O.; Borrias-Essers, M.C.; Ryder, L.P.; Koch, C.; Garred, P. Mannose-binding lectin engagement with late apoptotic and necrotic cells. Eur J. Immunol. 2003, 33, 2853-2863.

77. Thiel, S.; Petersen, S.V.; Vorup-Jensen, T.; Matsushita, M.; Fujita, T.; Stover, C.M.; Schwaeble, W.J.; Jensenius, J.C. Interaction of $\mathrm{Clq}$ and mannan-binding lectin (MBL) with $\mathrm{C} 1 \mathrm{r}, \mathrm{C} 1 \mathrm{~s}$, MBL-associated serine proteases 1 and 2, and the MBL-associated protein Map19. J. Immunol. 2000, 165, 878-887.

78. Ambrus, G.; Gal, P.; Kojima, M.; Szilagyi, K.; Balczer, J.; Antal, J.; Graf, L.; Laich, A.; Moffatt, B.E.; Schwaeble, W.; et al. Natural substrates and inhibitors of mannan-binding lectin-associated serine protease-1 and -2: A study on recombinant catalytic fragments. J. Immunol. 2003, 170, 1374-1382.

79. Gulla, K.C.; Gupta, K.; Krarup, A.; Gal, P.; Schwaeble, W.J.; Sim, R.B.; O'Connor, C.D.; Hajela, $\mathrm{K}$. Activation of mannan-binding lectin-associated serine proteases leads to generation of a fibrin clot. Immunology 2009, 129, 482-495.

80. Krarup, A.; Wallis, R.; Presanis, J.S.; Gal, P.; Sim, R.B. Simultaneous activation of complement and coagulation by MBL-associated serine protease 2. PLoS One 2007, 2, e623.

81. Matsushita, M.; Thiel, S.; Jensenius, J.C.; Terai, I.; Fujita, T. Proteolytic activities of two types of mannose-binding lectin-associated serine protease. J. Immunol. 2000, 165, 2637-2642.

82. Hajela, K.; Kojima, M.; Ambrus, G.; Wong, K.H.; Moffatt, B.E.; Ferluga, J.; Hajela, S.; Gal, P.; $\mathrm{Sim}, \mathrm{R} . \mathrm{B}$. The biological functions of MBL-associated serine proteases (MASPs). Immunobiology 2002, 205, 467-475.

83. Krarup, A.; Gulla, K.C.; Gal, P.; Hajela, K.; Sim, R.B. The action of MBL-associated serine protease 1 (MASP1) on factor XIII and fibrinogen. Biochim. Biophys. Acta 2008, 1784, 1294-1300.

84. Megyeri, M.; Mako, V.; Beinrohr, L.; Doleschall, Z.; Prohaszka, Z.; Cervenak, L.; Zavodszky, P.; Gal, P. Complement protease MASP-1 activates human endothelial cells: PAR4 activation is a link between complement and endothelial function. J. Immunol. 2009, 183, 3409-3416. 
85. Cortesio, C.L.; Jiang, W. Mannan-binding lectin-associated serine protease 3 cleaves synthetic peptides and insulin-like growth factor-binding protein 5. Arch. Biochem. Biophys. 2006, 449, 164-170.

86. Brown, K.S.; Keogh, M.J.; Tagiuri, N.; Grainge, M.J.; Presanis, J.S.; Ryder, S.D.; Irving, W.L.; Ball, J.K.; Sim, R.B.; Hickling, T.P. Severe fibrosis in hepatitis C virus-infected patients is associated with increased activity of the mannan-binding lectin (MBL)/MBL-associated serine protease 1 (MASP-1) complex. Clin. Exp. Immunol. 2007, 147, 90-98.

87. Terai, I.; Kobayashi, K.; Matsushita, M.; Miyakawa, H.; Mafune, N.; Kikuta, H. Relationship between gene polymorphisms of mannose-binding lectin (MBL) and two molecular forms of MBL. Eur. J. Immunol. 2003, 33, 2755-2763.

88. Larsen, F.; Madsen, H.O.; Sim, R.B.; Koch, C.; Garred, P. Disease-associated mutations in human mannose-binding lectin compromise oligomerization and activity of the final protein. J. Biol. Chem. 2004, 279, 21302-21311.

89. Madsen, H.O.; Garred, P.; Thiel, S.; Kurtzhals, J.A.; Lamm, L.U.; Ryder, L.P.; Svejgaard, A. Interplay between promoter and structural gene variants control basal serum level of mannanbinding protein. J. Immunol. 1995, 155, 3013-3020.

90. Crosdale, D.J.; Ollier, W.E.; Thomson, W.; Dyer, P.A.; Jensenious, J.; Johnson, R.W.; Poulton, K.V. Mannose binding lectin (MBL) genotype distributions with relation to serum levels in UK Caucasoids. Eur. J. Immunogenet. 2000, 27, 111-117.

91. Garred, P.; Larsen, F.; Seyfarth, J.; Fujita, R.; Madsen, H.O. Mannose-binding lectin and its genetic variants. Genes Immun. 2006, 7, 85-94.

92. Matsushita, M.; Hijikata, M.; Ohta, Y.; Iwata, K.; Matsumoto, M.; Nakao, K.; Kanai, K.; Yoshida, N.; Baba, K.; Mishiro, S. Hepatitis $\mathrm{C}$ virus infection and mutations of mannose-binding lectin gene MBL. Arch. Virol. 1998, 143, 645-651.

93. Matsushita, M.; Hijikata, M.; Ohta, Y.; Mishiro, S. Association of mannose-binding lectin gene haplotype LXPA and LYPB with interferon-resistant hepatitis C virus infection in Japanese patients. J. Hepatol. 1998, 29, 695-700.

94. Sasaki, K.; Tsutsumi, A.; Wakamiya, N.; Ohtani, K.; Suzuki, Y.; Watanabe, Y.; Nakayama, N.; Koike, T. Mannose-binding lectin polymorphisms in patients with hepatitis $\mathrm{C}$ virus infection. Scand. J. Gastroenterol. 2000, 35, 960-965.

95. Koutsounaki, E.; Goulielmos, G.N.; Koulentaki, M.; Choulaki, C.; Kouroumalis, E.; Galanakis, E. Mannose-binding lectin MBL2 gene polymorphisms and outcome of hepatitis C virus-infected patients. J. Clin. Immunol. 2008, 28, 495-500.

96. Kilpatrick, D.C.; Delahooke, T.E.; Koch, C.; Turner, M.L.; Hayes, P.C. Mannan-binding lectin and hepatitis C infection. Clin. Exp. Immunol. 2003, 132, 92-95.

97. Iacob, R.E.; Perdivara, I.; Przybylski, M.; Tomer, K.B. Mass spectrometric characterization of glycosylation of hepatitis $\mathrm{C}$ virus E2 envelope glycoprotein reveals extended microheterogeneity of N-glycans. J. Am. Soc. Mass. Spectrom. 2008, 19, 428-444.

98. Worthley, D.L.; Johnson, D.F.; Eisen, D.P.; Dean, M.M.; Heatley, S.L.; Tung, J.P.; Scott, J.; Padbury, R.T.; Harley, H.A.; Bardy, P.G.; et al. Donor mannose-binding lectin deficiency increases the likelihood of clinically significant infection after liver transplantation. Clin. Infect. Dis. 2009, 48, 410-417. 
99. Akaiwa, M.; Yae, Y.; Sugimoto, R.; Suzuki, S.O.; Iwaki, T.; Izuhara, K.; Hamasaki, N. Hakata antigen, a new member of the ficolin/opsonin p35 family, is a novel human lectin secreted into bronchus/alveolus and bile. J. Histochem. Cytochem. 1999, 47, 777-786.

100. Keirstead, N.D.; Lee, C.; Yoo, D.; Brooks, A.S.; Hayes, M.A. Porcine plasma ficolin binds and reduces infectivity of porcine reproductive and respiratory syndrome virus (PRRSV) in vitro. Antivir. Res. 2008, 77, 28-38.

101. Hamed, M.R.; Brown, R.J.P.B.; McClure, C.P.; Urbanowicz, R.A.; Irving, W.L.; Ball, J.K.; Hickling, T.P.; Tarr, A.W. Neutralization of hepatitis $C$ virus entry by human defence collagen L-ficolin. University of Nottingham, Nottingham, UK. Unpublished work, 2012.

102. Munthe-Fog, L.; Hummelshoj, T.; Hansen, B.E.; Koch, C.; Madsen, H.O.; Skjodt, K.; Garred, P. The impact of FCN2 polymorphisms and haplotypes on the ficolin-2 serum levels. Scand. J. Immunol. 2007, 65, 383-392.

103. Gulla, K.C.; Gupta, K.; Krarup, A.; Gal, P.; Schwaeble, W.J.; Sim, R.B.; O'Connor, C.D.; Hajela, $\mathrm{K}$. Activation of mannan-binding lectin-associated serine proteases leads to generation of a fibrin clot. Immunology 2010, 129, 482-495.

104. Urban, T.J.; Thompson, A.J.; Bradrick, S.S.; Fellay, J.; Schuppan, D.; Cronin, K.D.; Hong, L.; McKenzie, A.; Patel, K.; Shianna, K.V.; et al. IL28b genotype is associated with differential expression of intrahepatic interferon-stimulated genes in patients with chronic hepatitis C. Hepatology 2010, 52, 1888-1896.

105. McCarthy, J.J.; Li, J.H.; Thompson, A.; Suchindran, S.; Lao, X.Q.; Patel, K.; Tillmann, H.L.; Muir, A.J.; McHutchison, J.G. Replicated association between an IL28B gene variant and a sustained response to pegylated interferon and ribavirin. Gastroenterology 2010, 138, 2307-2314.

106. Gewurz, H.; Zhang, X.H.; Lint, T.F. Structure and function of the pentraxins. Curr. Opin. Immunol. 1995, 7, 54-64.

107. Pepys, M.B.; Hirschfield, G.M. C-reactive protein: A critical update. J. Clin. Invest. 2003, 111, $1805-1812$.

108. Baruah, P.; Dumitriu, I.E.; Peri, G.; Russo, V.; Mantovani, A.; Manfredi, A.A.; Rovere-Querini, P. The tissue pentraxin PTX3 limits C1q-mediated complement activation and phagocytosis of apoptotic cells by dendritic cells. J. Leukoc. Biol. 2006, 80, 87-95.

109. Kessel, A.; Elias, G.; Pavlotzky, E.; Zuckerman, E.; Rosner, I.; Toubi, E. Anti-C-reactive protein antibodies in chronic hepatitis $\mathrm{C}$ infection: Correlation with severity and autoimmunity. Hum. Immunol. 2007, 68, 844-848.

110. Alles, V.V.; Bottazzi, B.; Peri, G.; Golay, J.; Introna, M.; Mantovani, A. Inducible expression of PTX3, a new member of the pentraxin family, in human mononuclear phagocytes. Blood 1994, 84, 3483-3493.

111. Reading, P.C.; Bozza, S.; Gilbertson, B.; Tate, M.; Moretti, S.; Job, E.R.; Crouch, E.C.; Brooks, A.G.; Brown, L.E.; Bottazzi, B.; et al. Antiviral activity of the long chain pentraxin PTX3 against influenza viruses. J. Immunol. 2008, 180, 3391-3398.

112. Bozza, S.; Bistoni, F.; Gaziano, R.; Pitzurra, L.; Zelante, T.; Bonifazi, P.; Perruccio, K.; Bellocchio, S.; Neri, M.; Iorio, A.M.; et al. Pentraxin 3 protects from MCMV infection and reactivation through TLR sensing pathways leading to IRF3 activation. Blood 2006, 108, 3387-3396. 
113. Nauta, A.J.; Bottazzi, B.; Mantovani, A.; Salvatori, G.; Kishore, U.; Schwaeble, W.J.; Gingras, A.R.; Tzima, S.; Vivanco, F.; Egido, J.; et al. Biochemical and functional characterization of the interaction between pentraxin 3 and C1q. Eur. J. Immunol. 2003, 33, 465-473.

114. Peri, G.; Introna, M.; Corradi, D.; Iacuitti, G.; Signorini, S.; Avanzini, F.; Pizzetti, F.; Maggioni, A.P.; Moccetti, T.; Metra, M.; et al. PTX3, a prototypical long pentraxin, is an early indicator of acute myocardial infarction in humans. Circulation 2000, 102, 636-641.

115. Baruah, P.; Propato, A.; Dumitriu, I.E.; Rovere-Querini, P.; Russo, V.; Fontana, R.; Accapezzato, D.; Peri, G.; Mantovani, A.; Barnaba, V.; et al. The pattern recognition receptor PTX3 is recruited at the synapse between dying and dendritic cells, and edits the cross-presentation of self, viral, and tumor antigens. Blood 2006, 107, 151-158.

116. Jensen, L.E.; Whitehead, A.S. Regulation of serum amyloid A protein expression during the acute-phase response. Biochem. J. 1998, 334, 489-503.

117. Smith, J.W.; McDonald, T.L. Production of serum amyloid A and C-reactive protein by HepG2 cells stimulated with combinations of cytokines or monocyte conditioned media: The effects of prednisolone. Clin. Exp. Immunol. 1992, 90, 293-299.

118. Song, C.; Hsu, K.; Yamen, E.; Yan, W.; Fock, J.; Witting, P.K.; Geczy, C.L.; Freedman, S.B. Serum amyloid A induction of cytokines in monocytes/macrophages and lymphocytes. Atherosclerosis 2009, 207, 374-383.

119. Baranova, I.N.; Vishnyakova, T.G.; Bocharov, A.V.; Kurlander, R.; Chen, Z.; Kimelman, M.L.; Remaley, A.T.; Csako, G.; Thomas, F.; Eggerman, T.L.; et al. Serum amyloid A binding to CLA1 (CD36 and LIMPII analogous-1) mediates serum amyloid A protein-induced activation of ERK1/2 and p38 mitogen-activated protein kinases. J. Biol. Chem. 2005, 280, 8031-8040.

120. van der Westhuyzen, D.R.; Cai, L.; de Beer, M.C.; de Beer, F.C. Serum amyloid A promotes cholesterol efflux mediated by scavenger receptor B-I. J. Biol. Chem. 2005, 280, 35890-35895.

121. Marsche, G.; Frank, S.; Raynes, J.G.; Kozarsky, K.F.; Sattler, W.; Malle, E. The lipidation status of acute-phase protein serum amyloid A determines cholesterol mobilization via scavenger receptor class B, type I. Biochem. J. 2007, 402, 117-124.

122. Bartosch, B.; Vitelli, A.; Granier, C.; Goujon, C.; Dubuisson, J.; Pascale, S.; Scarselli, E.; Cortese, R.; Nicosia, A.; Cosset, F.L. Cell entry of hepatitis $C$ virus requires a set of co-receptors that include the CD81 tetraspanin and the SR-B1 scavenger receptor. J. Biol. Chem. 2003, 278, 41624-41630.

123. Catanese, M.T.; Ansuini, H.; Graziani, R.; Huby, T.; Moreau, M.; Ball, J.K.; Paonessa, G.; Rice, C.M.; Cortese, R.; Vitelli, A.; et al. Role of scavenger receptor class B type I in hepatitis C virus entry: Kinetics and molecular determinants. J. Virol. 2009, 84, 34-43.

124. Scarselli, E.; Ansuini, H.; Cerino, R.; Roccasecca, R.M.; Acali, S.; Filocamo, G.; Traboni, C.; Nicosia, A.; Cortese, R.; Vitelli, A. The human scavenger receptor class B type I is a novel candidate receptor for the hepatitis $\mathrm{C}$ virus. EMBO J. 2002, 21, 5017-5025.

125.Zeisel, M.B.; Koutsoudakis, G.; Schnober, E.K.; Haberstroh, A.; Blum, H.E.; Cosset, F.L.; Wakita, T.; Jaeck, D.; Doffoel, M.; Royer, C.; et al. Scavenger receptor class B type I is a key host factor for hepatitis $\mathrm{C}$ virus infection required for an entry step closely linked to CD81. Hepatology 2007, 46, 1722-1731. 
126. Bartosch, B.; Verney, G.; Dreux, M.; Donot, P.; Morice, Y.; Penin, F.; Pawlotsky, J.M.; Lavillette, D.; Cosset, F.L. An interplay between hypervariable region 1 of the hepatitis $\mathrm{C}$ virus E2 glycoprotein, the scavenger receptor BI, and high-density lipoprotein promotes both enhancement of infection and protection against neutralizing antibodies. J. Virol. 2005, 79, 8217-8229.

127. Voisset, C.; Callens, N.; Blanchard, E.; Op De Beeck, A.; Dubuisson, J.; Vu-Dac, N. High density lipoproteins facilitate hepatitis $\mathrm{C}$ virus entry through the scavenger receptor class B type I. J. Biol. Chem. 2005, 280, 7793-7799.

128. Meunier, J.C.; Engle, R.E.; Faulk, K.; Zhao, M.; Bartosch, B.; Alter, H.; Emerson, S.U.; Cosset, F.L.; Purcell, R.H.; Bukh, J. Evidence for cross-genotype neutralization of hepatitis C virus pseudoparticles and enhancement of infectivity by apolipoprotein C1. Proc. Natl. Acad. Sci. U. S. A. 2005, $102,4560-4565$.

129. Lavie, M.; Voisset, C.; Vu-Dac, N.; Zurawski, V.; Duverlie, G.; Wychowski, C.; Dubuisson, J. Serum amyloid A has antiviral activity against hepatitis $C$ virus by inhibiting virus entry in a cell culture system. Hepatology 2006, 44, 1626-1634.

130. Cai, Z.; Cai, L.; Jiang, J.; Chang, K.S.; van der Westhuyzen, D.R.; Luo, G. Human serum amyloid A protein inhibits hepatitis C virus entry into cells. J. Virol. 2007, 81, 6128-6133.

131. Miwata, H.; Yamada, T.; Okada, M.; Kudo, T.; Kimura, H.; Morishima, T. Serum amyloid A protein in acute viral infections. Arch. Dis. Child. 1993, 68, 210-214.

132. Norata, G.D.; Pirillo, A.; Ammirati, E.; Catapano, A.L. Emerging role of high density lipoproteins as a player in the immune system. Atherosclerosis 2012, 220, 11-21.

133. Klotman, M.E.; Chang, T.L. Defensins in innate antiviral immunity. Nat. Rev. Immunol. 2006, 6, 447-456.

134. Martin, E.; Ganz, T.; Lehrer, R.I. Defensins and other endogenous peptide antibiotics of vertebrates. J. Leukoc. Biol. 1995, 58, 128-136.

135. Seidel, A.; Ye, Y.; de Armas, L.R.; Soto, M.; Yarosh, W.; Marcsisin, R.A.; Tran, D.; Selsted, M.E.; Camerini, D. Cyclic and acyclic defensins inhibit human immunodeficiency virus type-1 replication by different mechanisms. PLoS One 2011, 5, e9737.

136. Prohaszka, Z.; Nemet, K.; Csermely, P.; Hudecz, F.; Mezo, G.; Fust, G. Defensins purified from human granulocytes bind $\mathrm{Clq}$ and activate the classical complement pathway like the transmembrane glycoprotein gp41 of HIV-1. Mol. Immunol. 1997, 34, 809-816.

137. Ryan, L.K.; Dai, J.; Yin, Z.; Megjugorac, N.; Uhlhorn, V.; Yim, S.; Schwartz, K.D.; Abrahams, J.M.; Diamond, G.; Fitzgerald-Bocarsly, P. Modulation of human beta-defensin-1 (hBD-1) in plasmacytoid dendritic cells (pDC), monocytes, and epithelial cells by influenza virus, herpes simplex virus, and sendai virus and its possible role in innate immunity. J. Leukoc. Biol. 2011, 90, 343-356.

138. Kreuter, A.; Skrygan, M.; Gambichler, T.; Brockmeyer, N.H.; Stucker, M.; Herzler, C.; Potthoff, A.; Altmeyer, P.; Pfister, H.; Wieland, U. Human papillomavirus-associated induction of human beta-defensins in anal intraepithelial neoplasia. Br. J. Dermatol. 2009, 160, 1197-1205.

139. Bhat, S.; Song, Y.H.; Lawyer, C.; Milner, S.M. Modulation of the complement system by human beta-defensin 2. J. Burns Wounds 2007, 5, e10. 
140.Zapata, W.; Rodriguez, B.; Weber, J.; Estrada, H.; Quinones-Mateu, M.E.; Zimermman, P.A.; Lederman, M.M.; Rugeles, M.T. Increased levels of human beta-defensins mRNA in sexually HIV-1 exposed but uninfected individuals. Curr. HIV Res. 2008, 6, 531-538.

141. Daher, K.A.; Selsted, M.E.; Lehrer, R.I. Direct inactivation of viruses by human granulocyte defensins. J. Virol. 1986, 60, 1068-1074.

142. Aceti, A.; Mangoni, M.L.; Pasquazzi, C.; Fiocco, D.; Marangi, M.; Miele, R.; Zechini, B.; Borro, M.; Versace, I.; Simmaco, M. Alpha-defensin increase in peripheral blood mononuclear cells from patients with hepatitis C virus chronic infection. J. Viral. Hepat. 2006, 13, 821-827.

143. Prince, A.M.; Huima-Byron, T.; Parker, T.S.; Levine, D.M. Visualization of hepatitis C virions and putative defective interfering particles isolated from low-density lipoproteins. J. Viral. Hepat. 1996, 3, 11-17.

144. Thomssen, R.; Bonk, S.; Thiele, A. Density heterogeneities of hepatitis C virus in human sera due to the binding of beta-lipoproteins and immunoglobulins. Med. Microbiol. Immunol. 1993, 182, 329-334.

145. Andre, P.; Komurian-Pradel, F.; Deforges, S.; Perret, M.; Berland, J.L.; Sodoyer, M.; Pol, S.; Brechot, C.; Paranhos-Baccala, G.; Lotteau, V. Characterization of low- and very-low-density hepatitis C virus RNA-containing particles. J. Virol. 2002, 76, 6919-6928.

146. Meunier, J.C.; Russell, R.S.; Engle, R.E.; Faulk, K.N.; Purcell, R.H.; Emerson, S.U. Apolipoprotein $\mathrm{C} 1$ association with hepatitis C virus. J. Virol. 2008, 82, 9647-9656.

147. Chang, K.S.; Jiang, J.; Cai, Z.; Luo, G. Human apolipoprotein E is required for infectivity and production of hepatitis C virus in cell culture. J. Virol. 2007, 81, 13783-13793.

148. Tao, W.; Xu, C.; Ding, Q.; Li, R.; Xiang, Y.; Chung, J.; Zhong, J. A single point mutation in E2 enhances hepatitis $\mathrm{C}$ virus infectivity and alters lipoprotein association of viral particles. Virology 2009, 395, 67-76.

149. Grove, J.; Nielsen, S.; Zhong, J.; Bassendine, M.F.; Drummer, H.E.; Balfe, P.; McKeating, J.A. Identification of a residue in hepatitis $\mathrm{C}$ virus $\mathrm{E} 2$ glycoprotein that determines scavenger receptor BI and CD81 receptor dependency and sensitivity to neutralizing antibodies. J. Virol. 2008, 82, 12020-12029.

150. Falkowska, E.; Kajumo, F.; Garcia, E.; Reinus, J.; Dragic, T. Hepatitis C virus envelope glycoprotein E2 glycans modulate entry, CD81 binding, and neutralization. J. Virol. 2007, 81, 8072-8079.

151. Helle, F.; Goffard, A.; Morel, V.; Duverlie, G.; McKeating, J.; Keck, Z.Y.; Foung, S.; Penin, F.; Dubuisson, J.; Voisset, C. The neutralizing activity of anti-hepatitis $\mathrm{C}$ virus antibodies is modulated by specific glycans on the E2 envelope protein. J. Virol. 2007, 81, 8101-8111.

152. Brown, R.J.; Tarr, A.W.; McClure, C.P.; Juttla, V.S.; Tagiuri, N.; Irving, W.L.; Ball, J.K. Cross-genotype characterization of genetic diversity and molecular adaptation in hepatitis $\mathrm{C}$ virus envelope glycoprotein genes. J. Gen. Virol. 2007, 88, 458-469.

153. Farci, P.; Shimoda, A.; Coiana, A.; Diaz, G.; Peddis, G.; Melpolder, J.C.; Strazzera, A.; Chien, D.Y.; Munoz, S.J.; Balestrieri, A.; et al. The outcome of acute hepatitis C predicted by the evolution of the viral quasispecies. Science 2000, 288, 339-344. 
154. Job, E.R.; Deng, Y.M.; Tate, M.D.; Bottazzi, B.; Crouch, E.C.; Dean, M.M.; Mantovani, A.; Brooks, A.G.; Reading, P.C. Pandemic H1N1 influenza A viruses are resistant to the antiviral activities of innate immune proteins of the collectin and pentraxin superfamilies. J. Immunol. 2010, 185, 4284-4291.

155. Qin, X.; Gao, B. The complement system in liver diseases. Cell Mol. Immunol. 2006, 3, 333-340.

156. Bataller, R.; Brenner, D.A. Liver fibrosis. J. Clin. Invest. 2005, 115, 209-218.

157. Levy, M.T.; McCaughan, G.W.; Marinos, G.; Gorrell, M.D. Intrahepatic expression of the hepatic stellate cell marker fibroblast activation protein correlates with the degree of fibrosis in hepatitis $\mathrm{C}$ virus infection. Liver 2002, 22, 93-101.

158. Gaca, M.D.; Zhou, X.; Benyon, R.C. Regulation of hepatic stellate cell proliferation and collagen synthesis by proteinase-activated receptors. J. Hepatol. 2002, 36, 362-369.

159. Knight, V.; Tchongue, J.; Lourensz, D.; Tipping, P.; Sievert, W. Protease-activated receptor 2 promotes experimental liver fibrosis and activates human hepatic stellate cells. Hepatology 2011, doi:10.1002/hep.24784.

160. Alves Pedroso, M.L.; Boldt, A.B.; Pereira-Ferrari, L.; Steffensen, R.; Strauss, E.; Jensenius, J.C.; Ioshii, S.O.; Messias-Reason, I. Mannan-binding lectin MBL2 gene polymorphism in chronic hepatitis C: Association with the severity of liver fibrosis and response to interferon therapy. Clin. Exp. Immunol. 2008, 152, 258-264.

161. El Saadany, S.A.; Ziada, D.H.; Farrag, W.; Hazaa, S. Fibrosis severity and mannan-binding lectin (MBL)/MBL-associated serine protease 1 (MASP-1) complex in HCV-infected patients. Arab. J. Gastroenterol. 2011, 12, 68-73.

162. Agnello, V.; Chung, R.T.; Kaplan, L.M. A role for hepatitis C virus infection in type II cryoglobulinemia. N. Engl. J. Med. 1992, 327, 1490-1495.

163. De Re, V.; Sansonno, D.; Simula, M.P.; Caggiari, L.; Gasparotto, D.; Fabris, M.; Tucci, F.A.; Racanelli, V.; Talamini, R.; Campagnolo, M.; et al. HCV-NS3 and IgG-Fc crossreactive IgM in patients with type II mixed cryoglobulinemia and B-cell clonal proliferations. Leukemia 2006, 20, 1145-1154.

164. Cacoub, P.; Musset, L.; Amoura, Z.; Guilani, P.; Chabre, H.; Lunel, F.; Poynard, T.; Opolon, P.; Piette, J.C. Anticardiolipin, anti-beta2-glycoprotein I, and antinucleosome antibodies in hepatitis C virus infection and mixed cryoglobulinemia. Multivirc group. J. Rheumatol. 1997, 24, 2139-2144.

165. Lienesch, D.W.; Sherman, K.E.; Metzger, A.; Shen, G.Q. Anti-Clq antibodies in patients with chronic hepatitis C infection. Clin. Exp. Rheumatol. 2006, 24, 183-185.

166. Sansonno, D.; Tucci, F.A.; Ghebrehiwet, B.; Lauletta, G.; Peerschke, E.I.; Conteduca, V.; Russi, S.; Gatti, P.; Sansonno, L.; Dammacco, F. Role of the receptor for the globular domain of C1q protein in the pathogenesis of hepatitis $\mathrm{C}$ virus-related cryoglobulin vascular damage. J. Immunol. 2009, 183, 6013-6020.

167. Sansonno, D.; Lauletta, G.; Nisi, L.; Gatti, P.; Pesola, F.; Pansini, N.; Dammacco, F. Non-enveloped HCV core protein as constitutive antigen of cold-precipitable immune complexes in type II mixed cryoglobulinaemia. Clin. Exp. Immunol. 2003, 133, 275-282.

168. Ohsawa, I.; Ohi, H.; Tamano, M.; Endo, M.; Fujita, T.; Satomura, A.; Hidaka, M.; Fuke, Y.; Matsushita, M. Cryoprecipitate of patients with cryoglobulinemic glomerulonephritis contains molecules of the lectin complement pathway. Clin. Immunol. 2001, 101, 59-66. 
169. Rosa, D.; Saletti, G.; De Gregorio, E.; Zorat, F.; Comar, C.; D'Oro, U.; Nuti, S.; Houghton, M.; Barnaba, V.; Pozzato, G.; et al. Activation of naive B lymphocytes via CD81, a pathogenetic mechanism for hepatitis C virus-associated B lymphocyte disorders. Proc. Natl. Acad. Sci. U. S. A. 2005, 102, 18544-18549.

170. Machida, K.; Cheng, K.T.; Pavio, N.; Sung, V.M.; Lai, M.M. Hepatitis C virus E2-CD81 interaction induces hypermutation of the immunoglobulin gene in B cells. J. Virol. 2005, 79, 8079-8089.

171. Yao, Z.Q.; Eisen-Vandervelde, A.; Ray, S.; Hahn, Y.S. HCV core/gC1qR interaction arrests T cell cycle progression through stabilization of the cell cycle inhibitor p27KIP1. Virology 2003, 314, 271-282.

172. Yao, Z.Q.; Shata, M.T.; Tricoche, N.; Shan, M.M.; Brotman, B.; Pfahler, W.; Hahn, Y.S.; Prince, A.M. gClqR expression in chimpanzees with resolved and chronic infection: Potential role of $\mathrm{HCV}$ core/gC1qR-mediated $\mathrm{T}$ cell suppression in the outcome of $\mathrm{HCV}$ infection. Virology 2006, 346, 324-337.

173. Rickert, R.C. Regulation of B lymphocyte activation by complement C3 and the B cell coreceptor complex. Curr. Opin. Immunol. 2005, 17, 237-243.

174. Nakayama, Y.; Kim, S.I.; Kim, E.H.; Lambris, J.D.; Sandor, M.; Suresh, M. C3 promotes expansion of CD8+ and CD4+ T cells in a Listeria monocytogenes infection. J. Immunol. 2009, 183, 2921-2931.

175. Suresh, M.; Molina, H.; Salvato, M.S.; Mastellos, D.; Lambris, J.D.; Sandor, M. Complement component 3 is required for optimal expansion of CD8+ T cells during a systemic viral infection. J. Immunol. 2003, 170, 788-794.

176. Friedman, H.M.; Wang, L.; Pangburn, M.K.; Lambris, J.D.; Lubinski, J. Novel mechanism of antibody-independent complement neutralization of herpes simplex virus type 1. J. Immunol. 2000, 165, 4528-4536.

177. Michelow, I.C.; Dong, M.; Mungall, B.A.; Yantosca, L.M.; Lear, C.; Ji, X.; Karpel, M.; Rootes, C.L.; Brudner, M.; Houen, G.; et al. A novel L-ficolin/mannose-binding lectin chimeric molecule with enhanced activity against ebola virus. J. Biol. Chem. 2010, 285, 24729-24739.

178. Tarr, A.W.; Urbanowicz, R.A.; Hamed, M.R.; Albecka, A.; McClure, C.P.; Brown, R.J.; Irving, W.L.; Dubuisson, J.; Ball, J.K. Hepatitis C patient-derived glycoproteins exhibit marked differences in susceptibility to serum neutralizing antibodies: Genetic subtype defines antigenic but not neutralization serotype. J. Virol. 2011, 85, 4246-4257.

179. Meuleman, P.; Bukh, J.; Verhoye, L.; Farhoudi, A.; Vanwolleghem, T.; Wang, R.Y.; Desombere, I.; Alter, H.; Purcell, R.H.; Leroux-Roels, G. In vivo evaluation of the cross-genotype neutralizing activity of polyclonal antibodies against hepatitis C virus. Hepatology 2011, 53, 755-762.

(C) 2012 by the authors; licensee MDPI, Basel, Switzerland. This article is an open access article distributed under the terms and conditions of the Creative Commons Attribution license (http://creativecommons.org/licenses/by/3.0/). 